\title{
THE ECOLOGIC ANATOMY OF SOME PLANTS OF A PRAIRIE PROVINCE IN CENTRAL IOWA
}

ADA HAYDEN

A Dissertation SUBMitTed TO THE GRADUATE FACULTy OF THE IOWA STATE COLLEGE OF AGRICULTURE AND MECHANIC ARTS IN PARTIAL FULFILLMENT OF THE REQUIREMENTS FOR THE DEGREE OF DOCTOR OF PHILOSOPHY

NO. 5

REPRINTED FROM

THE AMERICAN JOURNAL OF BOTANY

VOL. VI, NOS. 2 AND 3, FEBRUARY AND MARCH, 1919 
Digitized by the Internet Archive in 2017 with funding from

University of Illinois Urbana-Champaign Alternates 


\title{
THE ECOLOGIC ANATOMY OF SOME PLANTS OF A PRAIRIE PROVINCE IN CENTRAL IOWA
}

\section{REMOTE STORAGE}

ADA HAYDEN

\begin{abstract}
A DISSERTATION SUBMITTED TO THE GRADUATE FACULTY OF THE IOWA STATE COLLEGE OF AGRICULTURE AND MECHANIC ARTS IN PARTIAL FULFILLMENT OF THE REQUIREMENTS FOR THE DEGREE OF DOCTOR OF PHILOSOPHY
\end{abstract}

$$
\text { NO. } 5
$$

REPRINTED FROM THE AMERICAN JOURNAL OF BOTANY VOL. VI, NOS. 2 AND 3, FEBRUARY AND WhRCH, 1919 



\section{ECOLOGIC FOLIAR ANATOMY}

\section{CONTENTS}

INTRODUCTION

METHOD

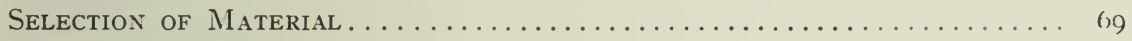

DISCUSSION

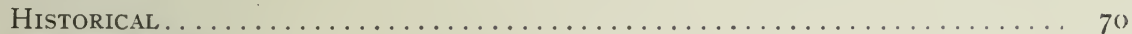

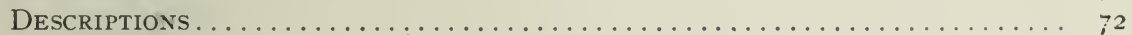

Illustrations.

Comparison of the Leaf Anatomy of the Upland and Alluvial Basin Plants . . . . . . . . . . . . . . . . . . . . . . . . . . 80

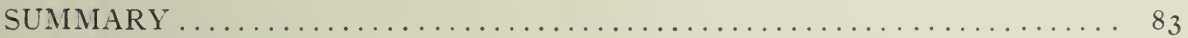

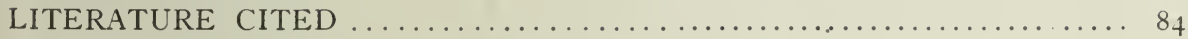

\section{ECOLOGIC SUBTERRANEAN ANATOMY}

\section{INTRODUCTION}

\section{CONTENTS}

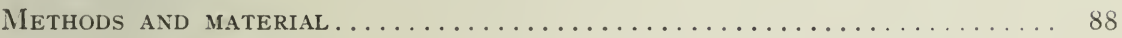

DISCUSSION

Historical. . . . . . . . . . . . . . . . . . . . . . . . . . 88

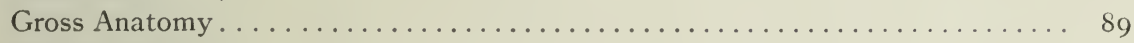

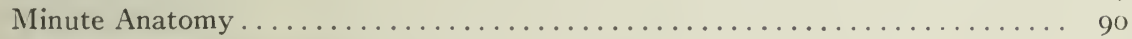

Description of Subterranean Organs. . . . . . . . . . . . . . . . . . 92

Analysis of the Anatomy of Subterranean Organs................... IoO

Comparison of Tissues of Subterranean Organs ................ IOI

SUMMARY ............................

LITERATURE CITED ............................. I03

EXPLANATION OF PLATES IX-XXVIII ................. 

[Reprinted from the AMerican Journal of Botany, 6: 69-85, January, I919.]

\section{THE ECOLOGIC FOLIAR ANATOMY OF SOME PLANTS OF A PRAIRIE PROVINCE IN CENTRAL IOWA}

\section{AdA HAYDEN}

\section{INTRODUCTION}

While exact records of environmental factors such as edaphic features, temperature, light, water, and biotic relationships are essential in the determination of the character of plant habitats, such data serve merely as an introduction to the investigation of the adaptation or equipment of plants for living in specific locations. While certain external characteristics, such as small or dissected leaves, are associated with sun plants, and broad leaves with shade plants, histological study reveals in greater detail any modifications of the normal type of tissues which are known to perform special activities. That the activities pertaining to the life processes of the plant are closely associated with its use of water is a well known physiological fact, so that not only the available water of the habitat but that which the plant actually uses or what passes through it in the transpiration stream is an important indicator of its toleration of conditions peculiar to its particular habitat. Work has been done by Livingston, Bakke, Shreve, and others on the transpiration of plants, and Bakke (I) has proposed a classification of plants as xerophytes, mesophytes, or hydrophytes on the basis of transpiration, which it seems is a very exact indicator of the available water used. While indices of transpiration would no doubt be desirable in connection with a morphological study, and would probably throw some light on whether a special type of tissue were characteristic of a species because of reaction to habitat or because of ancestral influence, the observations reported in this paper are confined to the morphological phase alone.

\section{SELECTION OF MATERIAL}

Leaves and subterranean portions were chosen for examination since these organs are critical "indicators" of absorption and transpiration of water and therefore are more closely related to the regulation of the water supply than stems, which serve primarily as conductors. The plants selected were representative species of their habitats, $i . e_{\text {., }}$ those species which were facies, or prominent in frequency or as to their vegetative perfection, for such plants may be regarded as instances of successful occupation of their respective environments. 


\section{METHODS}

Free-hand sections were made from typical mature leaves, usually selected from different plants, and from these the more representative sections were selected for mounts. After cutting, the sections were killed and fixed by immersion in hot alcohol, stained with a water-soluble safranin followed by haematoxylin, cleared in cedar oil and clove oil, and mounted in Canada balsam. Drawings of the leaves were made by camera lucida to a single scale of magnification. Qualitative data have been sought rather than quantitative. The thickness of the epidermis of leaves of one species as compared with the thickness of epidermis of another is not necessarily a positive or negative indicator of xerophytism, for one leaf may have trichomes plus a degree of thickness of epidermis found in the trichomeless leaf. Data concerning features regarded as "indicators" have been collected and relative proportions of tissues have been noted in individual plants.

\section{HisTORICAL}

While many physiologists are yet skeptical concerning the use of such terms as "reaction" of a plant to its habitat, "modification,". or "adaptation," careful investigation has shown that species do change their structure under different environmental conditions, although these words have been somewhat inexactly used and perhaps more exact terms might be evolved. Whether certain histological characters are due to environment or to ancestral influence can be determined only by some histological knowledge of closely allied forms and some experimental evidence regarding one species placed under different conditions. Schimper (I5), who has done extensive research of recognized excellence in histology, ecology, and plant geography, as well as some work in physiology, states: "All experiments have led to essentially similar results. External conditions which, either by diminishing the absorption of water or by accelerating its exit from the plant, disturb the equilibrium in a sense hostile to the plant, occasion, as a rule, the following deviations from normal structure: (I) Reduction of surface, the volume being assumed constant. (2) Diminution of intercellular spaces containing air. (3) Augmentation of vessels and sclerenchyma. (4) Lengthening of the palisade cells, frequent but not universal. (5) Increase in the thickness and amount of cutin of the outer wall of the epidermis. (6) Sinking of stomata. (7) Increased number of air-containing cells. (8) Supply of water-storing cells, such as double epidermis, aqueous tissue, mucilage cells.

Haberlandt (6) calls attention to two main principles of the anatomical structure of the photosynthetic system: $(a)$ the principle of maximum exposure of surface, and $(b)$ the principle of expeditious translocation.

The morphological structure of photosynthetic cells whose modifications are regarded as facilitating translocation are summarized by Haberlandt 
under three systems of structure. In system $\mathrm{I}$, the photosynthetic tissue is itself responsible for the removal of synthetic products from the entire organ. In system 2, distinct tissues are set apart for photosynthesis and for translocation, the synthetic products being transferred directly from one to the other. In the third and most efficient system, the photosynthetic products are not transferred directly from photosynthetic elements to the different channels but pass first through special intermediary tissues.

Sachs has shown by experiment that starch is quickly removed from specialized parenchyma cells. Haberlandt has observed that the girdle type of palisade shows a very rapid elimination of starch.

There is apparently diversity of views regarding development of palisade parenchyma, some of which Miss Starr (I8) in her study of the anatomy of dune plants summarized as follows: "Mrs. Clements (4) considered light the principal factor in the development of deep palisade. . . . Wagner reported that Alpine plants exposed to decreased transpiration did not show a reduction in palisade, and concluded that not transpiration but assimilation was more effective in producing that tissue. Pick (I4) thought the elongated form of the palisade is ancestral, but that for a strong development light is necessary; Dufour (5) agreed with him in this respect. Stahl related palisade development to light. Eberdt thought increase in palisade development is caused by assimilation and transpiration working together, and that light in itself is never the cause that calls forth palisade parenchyma. Vesque and Viet (20) concluded from their experiments that light and dry air (accelerating transpiration) result in a greater development of palisade. Bonnier (3) adds temperature considerations to these two factors. Kearney (9) considers excessive transpiration accountable for both increased palisade and succulency. Heinricher related equilateral structure to the vertical position of leaves and thought it due to sunny and dry situations, dryness being secondary to strong illumination, as some plants growing in damp situations have equilateral leaves."

Solereder (I9), who has compiled two comprehensive volumes on the systematic anatomy of the dicotyledons in which an enormous amount of data has been correlated, substantiates Schimper's views as to the anatomical indicators of xerophytism, and the reverse, but adds concerning the determination of adaptive features that these can be ascertained only by (I) examination of individuals of the same species from different habitats; (2) experimental treatment under definite conditions differing from those of the natural habitat; (3) the study of a larger group of plants undertaken in relation to the geographical area over which its members are distributed; and (4) comparative investigation. In speaking of the enumerated characters generally associated with xerophytic plants, such as thick cuticle, depressed stomata, etc., Solereder says that all these adaptations must not be supposed to be quite general, for if that were so, all plants which were subject to the same conditions would possess the same biological 
structural features even if they belonged to the most widely separated groups. This is only exceptionally true. Experience shows that one species reacts in one way, other species in a different way, under the action of the same stimulus, but that the reaction is often of the same kind in plants belonging to the same phylum. Thus one species protects itself against desiccation solely by means of mucilage receptacles, another by the development of hypodermal aqueous tissue, a third by enlargement of epidermal cells, and others by two or more of these features. Reiche, Volkens, and others have shown that climate and habitat do not impress any one definite type of anatomical structure upon all the species of a certain geographical area. Species possess a definite plasticity which, however, may vary in degree and direction in individuals; in such cases we may find discrepancies between structure and external conditions. According to Vesque and Areschoug the leaves of Nelumbium bear stomata on the upper side only, just like floating leaves. This fact is drawn from the theory that Nelumbium is derived from an ancestral form possessing floating leaves and is supported by the results of physiological researches in which it has again been emphatically shown that the anatomical structure is the product of two factors-adaptation and heredity. The second factor, which sometimes becomes more noticeable than the first, allows us to employ biological structural features to a very considerable extent for systematic purposes.

Biological characters serve principally for the diagnosis of species. Within the same group of affinity, these characters are often identical in all those forms in which they appear; or they may be constant for groups of allied species, for genera, or for small orders. Biological characters may be divided into those which differ qualitatively and those which differ quantitatively; of these the former have the greater systematic value. The presence of hypoderm in a leaf is a more important fact than the number of layers of hypoderm. Abundant material of the same species from different habitats and cultural conditions should be compared.

\section{DESCRIPTION OF LEAVES}

\section{Gramineae}

Andropogon scoparius Michx.

Habitat: Dry soil; hill crests; slopes.

${ }^{1}$ Orientation and arrangement: Blade ascending, appressed to stem when young; opposite.

Gross structure: Lanceolate; blade glabrant except near sheath.

Histology (fig. I, plate IX):

Outer walls of epidermis twice as thick as inner; bulliform cells prominent.

Parenchyma: Palisade cells concentric around the vascular bundles; spongy tissue between bundles; vascular tissue prominent.

Stomata small.

${ }^{1}$ The term orientation as here used refers to the plane in which the leaf blade lies, whether horizontal, vertical, or ascending. 
Summary: The bulliform cells are prominent. The thickened outer walls of the epidermal cells are indications of water conservation. This plant not only grows in a dry habitat but has abbreviated roots.

Bouteloua curtipendula (Michx.) Torr.

Habitat: Dry hill crests and slopes.

Orientation and arrangement: Ascending; alternate.

Gross structure: Small lancr olate-linear; flat or involute; scabrous above; sometimes pubescent beneath.

Histology (fig. 2, plate IX):

Outer walls of epidermis about twice as thick as inner walls; upper epidermal cells terminating in barb-like points at intervals; lower epidermis with trichomes; bulliform cells prominent.

Mesophyll reduced, represented by a radial row of palisade cells around the bundles.

Vascular tissue prominent, including a row of large water-storing cells.

Stomata small.

Summary: The thickened epidermal cells prominent, bulliform cells well developed; the conspicuous vascular tissue and the reduced photosynthetic tissue are marked indicators of conservational facilities. Bouteloua lives in drier areas and has a more restricted habitat than Andropogon scoparius.

Muhlenbergia mexicana (L.) Trin.

Habitat: Damp soil; low land; alluvial basin.

Orientation and arrangement: Ascending; alternate; somewhat appressed to stem.

Gross structure: Lanceolate-linear; small; scabrous.

Histology: Homogeneous (fig. 3, plate IX).

Outer walls of epidermis slightly thicker than inner; cells terminating in barb occasionally; bulliform cells not prominent.

Parenchyma: Spongy in appearance; of roundish to oval cells compactly arranged. Vascular tissue not prominent.

Stomata small.

Summary: This plant shows little tendency to conserve water. Vascular tissue is not so prominent as in grasses of drier habitats. Epidermis is not so specialized while photosynthetic tissue is fairly prominent.

Leersia oryzoides (L.) Sw.

Habitat: Alluvial basin; edge of swamp.

Orientation and arrangement: Ascending, somewhat appressed to stem: alternate.

Gross structure: Narrowly lanceolate; scabrous.

Histology: Homogeneous (fig. 4, plate IX).

Outer walls of epidermis slightly thickened; bulliform cells not prominent.

Vascular tissue fairly prominent.

Stomata small.

Parenchyma spongy; compact.

Summary: Water-conserving measures, though somewhat evident in the thickened outer wall of the epidermis and the differentiation of bulliform cells-are not so prominent as in Andropogon scoparius (fig. 4, plate IX) and Bouteloua curtipendula (fig. 2, plate IX), while photosynthetic tissue is better developed than it is in the leaves of the two last-named species.

\section{Polygonaceae}

Polygonum Muhlenbergii (Meisn.) Wats.

Habitat: Alluvial basin; wet soil and shallow water at edge of ponds. Not submerged.

Orientation and arrangement: Horizontal to ascending; petiolate. 
Gross structure: Lanceolate to ovate; water form smooth; land form scabrous.

Histology: Bifacial (figs. $5^{a}$ and $5 b$, plate IX).

Epidermis: Moderately thin-walled; slightly thicker on outer surface of water form; trichomes present on land form, also mucilagin us epidermal cells.

Stomata smaller on land than on water form.

Palisade parenchyma in two layers in both forms; the upper of irregular long cells, the lower of shorter and irregular cells; the land leaf is thicker than the water leaf, because the palisade parenchyma occupies $3 / 8$ of the parenchyma space in the water form and $5 / 9$ of the parenchyma space in the air form.

Spongy parenchyma about equally developed in both forms; loose.

Summary: These leaves indicate abundant water for needs with little provision for its conservation. The air leaf is a little thicker because of its increased thickness of the palisade, and its lower epidermis is equipped with trichomes and smaller stomata.

Anemone cylindrica Gray.

\section{Ranunculaceae}

Habitat: Dry, gravelly hill crests; dry, wind-swept.

Orientation and arrangement: Blade horizontal; radical leaves petiolate, involucrate leaves sessile.

Gross structure: Digitately cleft to parted; pubescent.

Histology: Bifacial (fig. 6, plate IX).

Epidermis with curved walls; outer walls about three times as thick as inner; large-celled compared with the parenchyma.

Stomata small; level with lower edge of epidermis.

Palisade parenchyma in 2 layers; slender; irregular; occupies $2 / 5$ parenchyma space.

Spongy parenchyma small-celled; close; compact; about $3 / 5$ the parenchyma space.

Summary: This leaf is equipped with trichomes, thick outer epidermal walls, and compact photosynthetic tissue.

Amorpha canescens Pursh.

\section{Leguminosae}

Habitat: Hill crests and dry hillsides.

Orientation and arrangement: Horizontal; petiolate; alternate.

Gross structure: Pinnately compound; hoary pubescent.

Histology: Subcentric (fig. 7, plate X).

Epidermis with approximately straight-sided cells; cells small; outer walls hardly thicker than the inner; trichomes present.

Palisade parenchyma in four layers graduated in size, longest on upper side; compact.

Spongy parenchyma absent.

Summary: The compact structure and the prominent trichomes show marked conservational features in accord with its specialized photosynthetic tissue. This plant, though living in dry situations, has a deep root which may reach a lower water table than the roots of some of its associates.

Baptisia leucantha T. \& G.

Habitat: Alluvial basin; moist soil.

Orientation and arrangement: Horizontal or somewhat inclined; almost sessile.

Gross structure: Palmately 3 -foliolate; leaflets wedge-shaped.

Histology: Subcentric (fig. $6 a$, plate X).

Walls of outer epidermis about three times as thick as inner; fairly large oblong cells with long axis horizontal.

Palisade parenchyma rather loose; cells medium-sized. Stomata slightly depressed. 
Summary: The somewhat thickened outer wall of the epidermis and the slightly depressed stomata show some tendency to check transpiration, but the prominent palisade parenchyma denotes marked photosynthetic activity. This plant not only lives in a fairly moist habitat, but has deep roots, so that its water supply seems insured.

\section{Rhamnaceae}

Ceanothus americanus $\mathrm{L}$.

Habitat: Dry, gravelly slopes.

Orientation and arrangement: Horizontal; alternate; short-petioled.

Gross structure: Ovate to oblong-ovate; somewhat pubescent.

Histology: Centric (fig. 8, plate X).

Epidermis: Thin-walled, the outer walls hardly thicker than the inner; cells small. Lower epidermis in scallops.

Stomata small; same plane with the lower epidermis.

Palisade parenchyma one layer on each side; lower layer rather irregular; occupies 2/3 parenchyma space.

Spongy parenchyma relatively large; compact; occupies $\mathrm{I} / 3$ the parenchyma space. Summary: While this plant lives in a dry, well-drained, exposed habitat, it does not show such protective characters as might be expected. Nothing is prominent except the compactness of structure. This may be accounted for by the fact that it has a relatively deep root which can reach a lower water table than the roots of some of its associates.

\section{Umbelliferae}

Eryngium yuccaefolium Michx.

Habitat: Dry soil; hill crests and slopes.

Orientation and arrangement: Ascending; stcm leaves alternate; radical leaves whorled; sessile.

Gross structure: Ovate-lanceolate, cuspidate-tipped; rigid, spinose.

Histology: Centric (fig. I6, plate XI).

Epidermal outer wall 3 times as thick as inner wall; large-celled.

Palisade parenchyma one layer on each side; irregular in shape and arrangement; occupies I/8 of parenchyma space; large-celled.

Spongy parenchyma cells elongated, their long axes at right angles to the palisade; large-celled.

Summary: Prominent large-celled photosynthetic tissue with prominent air space. Epidermal walls fairly well developed.

\section{Primulaceae}

Steironema lanceolata (Walt.) Gray.

Habitat: Alluvial basin; low, wet soil.

Orientation and arrangement: Horizontal to ascending; opposite; petioles graduated in length.

Gross structure: Lanceolate; glabrous.

Histology: Bifacial (fig. 9, plate X).

Epidermal cells large; horizontally oval; outer walls about twice as thick as inner.

Stomata slightly depressed.

Palisade parenchyma I layer; large, occupying $\mathrm{I} / 3$ the parenchyma space.

Spongy parenchyma loose.

Summary: This leaf structure indicates the photosynthetic activity with slight conservational tendencies, as suggested by the slightly thickened outer epidermal walls and the depressed stomata. 


\section{Apocynum cannabinum L.}

\section{Apocynaceae}

Habitat: Alluvial basin; wet soil.

Orientation and arrangement: Opposite, short-stemmed; horizontal to ascending.

Gross structure: Ovate to oblanceolate, glabrous or slightly pubescent.

Histology: Bifacial (fig. Io, plate X).

Upper and lower epidermis having thicker outer than inner walls. Lower epidermis scalloped, the walls in the middle of the scallops being 3 times as thick as the inner walls; outer walls curved.

Stomata small, slightly depressed; lower surface.

Palisade parenchyma 3 layers; slender; space occupied equal to that of spongy parenchyma.

Spongy parenchyma with moderate air space.

Summary: The thickenings of scallops seem practically equivalent to a uniformly thickened cuticle, for the thin places are opposite walls. This leaf shows indications of abundant water with adequate conservation facilities and a tendency to endure drought.

Asclepias verticillata $\mathrm{L}$.

\section{Asclepiadaceae}

Habitat: Alluvial basin. Basal slopes or low, level, moist areas.

Orientation and arrangement: Whorled, somewhat appressed toward the stem in an upward direction.

Gross structure: Linear with revolute margins, glabrous.

Histology: Bifacial (fig. I I, plate X).

Upper epidermis twice as thick as lower, outer wall thicker than inner in both cases; walls curved.

Stomata on under surface, with thick lower walls; level with epidermis.

Palisade parenchyma two layers; broad, large, wedge-shaped cells; occupies $3 / 8$ parenchyma space.

Spongy parenchyma twice as much as palisade, prominent air space; occupies $5 / 8$ parenchyma space.

Summary: The slender leaves, the reflexed edges, and the thick cuticular wall indicate protective, water-retentive characters, but the abundant photosynthetic tissue with much air space would indicate sufficient available water.

\section{Labiatae}

Physostegia virginiana (L.) Benth.

Habitat: Alluvial basin; wet soil.

Orientation and arrangement: Horizontal, opposite; sessile.

Gross structure: Lanceolate to oblong; glabrous.

Histology: Bifacial (fig. I3, plate XI).

Epidermal cells moderate-sized; outer walls both about two times as thick as inner walls.

Stomata small; on the level with lower surface of epidermis.

Palisade parenchyma, cells broad; two layers, occupying about I/2 parenchyma space.

Spongy parenchyma with large cells; much air space.

Summary: The surface stomata, the relatively thin-walled epidermis, the large-celled loose structure indicate photosynthetic activity and abundance of water without much tendency toward its conservation.

Mentha arvensis var. canadensis (L.) Briquet.

Habitat: Alluvial basin; damp soil.

Orientation and arrangement: Horizontal; opposite, lower leaves petioled. 
Gross structure: Oblong to ovate; minutely pubescent.

Histology: Subcentric (fig. 12, plate XI).

Epidermis, both sides about equal in size, small; outer wall of upper 3 times as thick as inner wall; lower with walls of equal thickness. Upper wall with trichomes.

Stomata slightly depressed with interior cavity prominent.

Palisade parenchyma consisting of three upper and two lower layers; slender cells; occupies $3 / 4$ parenchyma space.

Spongy parenchyma of two layers, resembling the palisade but twice as broad. Little air space.

Summary: The protective characters here seem to be the trichomes and the position of the stomata. Photosynthetic activity would seem to be prominent, according to the space provided for it.

Lycopus virginicus $\mathrm{L}$.

Habitat: Alluvial basin; moist soil.

Orientation and arrangement: Ascending: petioled; opposite.

Gross structure: Ovate to ovate-oblong; puberulent.

Histology: Bifacial (figs. $14 a, 14 b$, plate XI).

Upper epidermis thick-walled on outer side; lower epidermis uniformly thin-walled; wall of outer epidermis from a dry habitat twice as thick as that of a leaf from a moist habitat.

Palisade parenchyma I layer in leaves from a moist habitat; 3 layers in leaves from a dry habitat.

Spongy parenchyma loose; occupies about the same space in each case, but equivalent to $2 / 3$ the parenchyma space in the leaf from moist habitat and to $2 / 5$ the parenchyma space in the leaf from dry habitat.

Stomata depressed in leaf of dry habitat; on level of epidermal cells in the other case.

Summary: The leaf from the dry habitat shows a thicker epidermal wall, depressed stomata and greater palisade tissues, indicating better conservational tendencies.

Mimulus ringens $\mathrm{L}$.

\section{Scrophulariaceae}

Habitat: Alluvial basin; wet soil; near ponds.

Orientation and arrangement: Horizontal to ascending; sessile; clasping; opposite.

Gross structure: Oblong to lanceolate; glabrous.

Histology: Bifacial (figs. I $5 a$, I $5 b$, plate XI).

Variable epidermis; large-celled; fig. I $5 a$, walls uniformly thin; fig. I $5^{b}$, walls thickened on the outside.

Palisade parenchyma in fig. $15 a$, one layer; in fig. $15 b$, two layers.

Spongy parenchyma occupies about $\mathrm{I} / 2$ parenchyma space in both figs. $15 a$ and I $5 b$, though the cells are nearly twice as long in fig. I $5 a$ as in fig. $15 b$.

Stomata near surface level.

Summary: Leaf shown in fig. $15 a$ has no conservational devices; leaf in fig. ${ }^{5} b$ has evidently developed in this direction as shown by the thickened wall of the epidermis.

\section{Compositae}

Vernonia noveboracensis Willd.

Habitat: Alluvial basin; moist soil.

Orientation and arrangement: Horizontal to ascending; alternate; short-petioled.

Gross structure: Long lanceolate to lance-oblong; more or less pubescent beneath.

Histology: Subcentric (fig. 27, plate XIV). 
Epidermis of uniformly thin-walled cells; mostly oblong, slightly hairy on upper surface; longer hairs on lower surface; an occasional glandular trichome on upper surface; epidermis dips down into the palisade in folds at intervals.

Palisade parenchyma loose; large-celled.

Vascular bundle surrounded by large cells, apparently water reservoirs.

Summary: Photosynthetic tissue prominent; the thin-walled epidermis contrasts with the fairly numerous trichomes on both surfaces and with the presence of water reservoirs.

Artemisia ludoviciana Nutt.

Habitat: Dry slopes.

Orientation and arrangement: Horizontal to ascending; alternate.

Gross structure: Lanceolate; upper mostly entire; lower cut-lobed, toothed, or pinnatifid; whitened woolly.

Histology: Bifacial (fig. 24, plate XIII).

Epidermal cells variable in size; thickness of walls variable, not much thicker on the outside than on the inside; trichomes numerous on both sides, but most on the upper side of leaf.

Stomata small, not much depressed.

Palisade parenchyma 2 layers, occupying $\mathrm{I} / 3$ of the parenchyma space; largecelled.

Spongy parenchyma, cells large; rather loose.

Summary: Epidermal tissue not well developed except with regard to trichomes* photosynthetic tissue prominent.

Aster salicifolius Ait.

Habitat: Alluvial basin; low land; moist soil.

Orientation and arrangement: Horizontal to ascending; opposite; sessile.

Gross structure: Linear to linear-oblong; glabrous, sometimes scabrous.

Histology: Centric (fig. I7, plate XII).

Outer walls of epidermis about 3 times as thick as inside walls.

Stomata on both sides.

Palisade parenchyma, 2 layers on upper, I layer on lower side; occupies about 2/3 the parenchyma space. Cells medium-sized.

Spongy parenchyma, cells large; fairly compact.

Summary: Epidermis with fairly well developed cuticle though with stomata on both sides; photosynthetic tissue prominent.

Coreopsis palmata Nutt.

Habitat: Prairie slopes; dry to moist.

Orientation and arrangement: Ascending; sessile; opposite.

Gross structure: Wedge shaped; lobes broadly linear; glabrous.

Histology: Centric (fig. 20, plate XII).

Epidermis of small oblong cells; the outer walls thickened, 2 to 3 times the thickness of inner ones.

Palisade parenchyma occupies $2 / 3$ of parenchyma space; 3 layers above, 2 layers below.

Spongy parenchyma, cells large but fairly compact.

Resin ducts present.

Summary: Outer wall of epidermis fairly well developed; photosynthetic tissue prominent.

\section{Helianthus tuberosus L.}

Habitat: Slopes and level; dry to moist soil.

Orientation and arrangement: Horizontal; alternate.

Gross structure: Oblong-lanceolate; scabrous above, pubescent below. 
Histology: Bifacial (fig. I8, plate XII).

Upper epidermis with outer wall twice as thick as lower; wall of lower epidermis uniformly thin, but with numerous trichomes.

Palisade parenchyma of 3 layers, occupying $I / 2$ the parenchyma space.

Spongy parenchyma loose.

Summary: Photosynthetic tissue prominent; prominent air space; moderate conservational tendencies.

Helianthus grosseserratus Martens.

Habitat: Dry prairie; roadsides.

Orientation and arrangement: Horizontal to ascending; petioled; alternate.

Gross structure: Elongated lanceolate to ovate-lanceolate; glabrous above; finely pubescent beneath.

Histology: Bifacial (fig. I9, plate XII).

Outer wall of upper epidermis about 3 times as thick as inner; outer wall of lower epidermis about twice as thick as inner; cells small.

Palisade, 5 layers; medium-sized, occupying $2 / 3$ of parenchyma space.

Spongy parenchyma loose.

Summary: Epidermal tissue better developed in $H$. grosseserratus than in $H$. tuberosus.

Photosynthetic tissue is more compact.

Silphium laciniatum L.

Habitat: Rather dry priarie; sometimes moist slopes.

Orientation and arrangement: Stem leaves ascending; lower and root leaves vertical; alternate; petioled.

Gross structure: Pinnately parted, lobes lanceolate or linear, cut-lobed or pinnatifid; rough-bristly.

Histology: Subcentric (young leaf) (fig. 22, plate XII).

Epidermal cells square; with outer wall of epidermis 4 to 5 times as thick as inner wall.

Palisade in 5 layers, the longest at the top; fairly compact.

Summary: The well cuticularized epidermis indicates the ability to modify transpiration, while the prominent palisade implies pronounced photosynthetic activity.

Solidago rigida $\mathrm{L}$.

Habitat: Dry soil; ridges and hillsides.

Orientation and arrangement: Ascending, somewhat appressed; petioled; upper leaves sessile.

Gross structure: Oval or oblong; rough-hoary with minute pubescence.

Histology: Concentric (fig. 26, plate XIV).

Epidermal cells small with outer walls 3 times as thick as inner; trichomes on both sides.

Stomata on both sides.

Palisade parenchyma, 3 layers on upper and 2 on lower side; loose; occupies $2 / 3$ the parenchyma space.

Spongy parenchyma, small-celled; loose.

Stomata small, level with lower edge of epidermis.

Summary: Epidermis well equipped for conservation of water with the exception of stomata. Solereder states that stomata are often found on the upper sides of appressed leaves from dry habitats. Photosynthetic tissue well developed with prominent air space.

Solidago serotina Ait.

Habitat: Moist soil; slopes.

Orientation and arrangement: Horizontal to ascending, somewhat appressed; sessile.

Gross structure: Lanceolate to oblanceolate; glaucous. 
Histology: Bifacial (fig. 23, plate XIII).

Epidermis of irregular-sized cells, convex-walled; outer wall about I I/2 times as thick as inner.

Stomata on level with lower edge of the epidermis.

Palisade parenchyma, 2 layers; broad-celled.

Spongy parenchyma, large-celled; rather loose; occupies $2 / 3$ of parenchyma space.

Resin ducts present.

Summary: Has facilities for marked photosynthetic activity with slight protective device.

Solidago canadensis L.

Habitat: Moist soil; slopes.

Orientation and arrangement: Ascending, somewhat appressed; sessile.

Gross structure: Leaves narrowly lanceolate; glabrous above; minutely pubescent below.

Histology: Centric (fig. 25, plate XIII).

Epidermis thicker on upper than on lower side; outer walls about twice as thick as inner; trichomes on lower epidermis.

Stomata on both sides.

Palisade, 2 layers on upper surface and I-2 on lower surface, occupying $2 / 3$ the parenchyma space.

Spongy parenchyma of elongated cells running at right angles to the palisade; compact.

Resin ducts present.

Summary: A typical sun leaf with moderately developed protective devices to provide

for active photosynthesis. Consistent with its moderately moist habitat.

Solidago graminifolia (L.) Salisb.

Habitat: Alluvial basin; moist soil.

Orientation and arrangement: Horizontal to ascending; sessile.

Gross structure: Lance-linear; glabrous.

Histology: Centric (fig. 21, plate XII).

Epidermal cells small; outer wall $\mathrm{I} / 3$ thicker on upper than on lower side; outer wall of upper epidermis 3 times as thick as inner.

Palisade parenchyma, one layer on each side; cells rather small, oval; occupies I $/ 2$ parenchyma space of leaf.

Spongy parenchyma cells large; fairly compact.

Summary: Leaf fairly thin without trichomes or prominent protective device; well developed palisade and spongy parenchyma.

\section{Comparison of Leaf Anatomy of Upland and Alluvial Basin Plants}

The following plants were selected from two formations:

I. Prairie hill crest and slope: Andropogon scoparius, Bouteloua curtipendula, Anemone cylindrica, Amorpha canescens, Ceanothus americanus, Eryngium yuccaefolium, Artemisia canadensis, Solidago canadensis, Solidago rigida, Coreopsis palmata, Helianthus grosseserratus, Helianthus tuberosus.

Epidermis. . Of these twelve upland plants, all have a relatively thick outer-walled epidermis, or prominent trichomes if the wall is not thick. The presence of trichomes may be regarded as an anatomical equivalent of thick-walled epidermis. Two have prominent bulliform cells and vascular bundles. (Not enough data are recorded for stomata to warrant comparisons.) 
Parenchyma:

Subcentric leaves.

(I) Five layers palisade parenchyma.

(2) Four layers palisade.

Centric.

(I) Three upper, two lower layers palisade; spongy parenchyma loose.

(2) Three upper, two lower layers palisade; spongy parenchyma large-celled, compact.

(3) One upper, one lower layer palisade; spongy parenchyma large-celled, compact.

(4) One upper, one lower layer palisade; spongy parenchyma horizontally elongated.

Bifacial.

(I) Two layers of palisade cells; spongy parenchyma cells compact, small.

(2) Two layers of palisade cells; spongy parenchyma cells large, compact.

(3) Three layers of palisade cells; spongy parenchyma cells loose, elongated.

(4) Four layers of palisade cells; spongy parenchyma cells loose, elongated.

Radial palisade.

(I) Radial palisade; spongy parenchyma homogeneous.

(2) Radial palisade; spongy parenchyma homogeneous.

II. Alluvial basin: Leersia oryzoides, Muhlenbergia mexicana, Polygonum Muhlenbergii, Baptisia leucantha, Steironema lanceolata, Asclepias verticillata, A pocynum cannabinum, Mimulus ringens, Lycopus virginicus, Mentha canadensis, Physostegia virginiana, Solidago serotina, Solidago graminifolia, Vernonia noveboracensis, Silphium laciniatum, Aster salicifolius.

Epidermis: Of the sixteen alluvial basin plants examined, nine have a lower epidermal wall relatively thinner than that on the upper side. Ten are smooth.

Parenchyma:

Subcentric.

(I) Five layers palisade.

(2) Six layers palisade.

(3) Seven layers palisade.

Centric.

(I) One upper, two lower layers palisade; spongy parenchyma compact.

(2) Two upper, two lower layers palisade; spongy parenchyma compact. 
Bifacial.

(I) One layer palisade; spongy parenchyma loose.

(2) One layer palisade; spongy parenchyma loose.

(3) Two layers palisade; spongy parenchyma loose.

(4) Two layers palisade; spongy parenchyma loose.

(5) One-two layers palisade; spongy parenchyma loose.

(6) Three layers palisade; spongy parenchyma loose.

(7) One-three layers palisade; spongy parenchyma loose. Homogeneous.

(I) Rather compact mesophyll (Grass).

(2) Rather compact mesophyll (Grass).

Mimulus ringens studied in two habitats shows in one location two layers of palisade and a relatively thick outer epidermis, while in the moister habitat it has a uniformly thin epidermis and one layer of palisade with a thicker area of spongy parenchyma.

Polygonum Muhlenbergii shows a development of trichomes and a thicker palisade in leaves growing a few rods from a pond, while in shallow water its leaves are smooth and have a narrower palisade.

The Compositae and Gramineae by far exceed the other families in both number of representative species and individuals thereof.

Compositae. The Compositae show considerable variation of tissues, but are characterized by prominent palisade, four of the leaves having a centric structure, two subcentric, and four bifacial with deep palisade. The spongy tissue where present is loose. On low, wet land trichomes are generally not developed. Thickened epidermal walls are representative. The leaves are characterized by intensive photosynthetic activities. A tissue may be represented by an anatomical equivalent under different conditions indicating adaptability to habitat, manifested not only in anatomical characters but through evidence of wide distribution and great numbers.

All these Solidagos have well developed palisade but each of a different type. S. rigida has the driest habitat and shows the most prominent palisade, cuticle, and trichome development. The leaves appressed to the stem are associated with the presence of stomata on both sides. S. serotina has a moist habitat and shows practically no protective devices, having epidermal walls with loose spongy parenchyma. S. graminifolia, though growing in as moist, if not a moister, habitat than $S$. serotina, has a thicker cuticle and more compact parenchyma with two layers of palisade. $S$. canadensis has a fairly dry habitat though not so dry as that of S. rigida. Its compact tissue, prominent palisade, and thick-walled hairy epidermis seem consistent with its location.

Gramineae. The grasses of the lowland show a thinner epidermis, fewer and smaller bulliform cells, and less specialized palisade in the alluvial 
basin than in the upland prairie. Among the contributions dealing with Iowa grasses are the following: Emma Pammel Hansen (I2) studied the anatomy of Lolium perenne, Festuca elatior, F. tenella, and Bromus patulus. Emma Sirrine (I7) described and illustrated the anatomy of Bromus patulus, B. inermis, and B. secalinus. Pammel and Sirrine (13) investigated the anatomy of Sporobolus heterolepis, S. cryptandrus, S. Hookeri, S. vaginaeflorus, Panicum capillare, $P$. proliferum, and $P$. crusgalli. These investigators call attention to the difference in anatomy of plants growing in dry and in humid environments. C. R. Ball (2) examined Eragrostis reptans, E. pectinacea, E. Purshii, E. Frankii, E. Mexicana, and E. major, and describes the epidermal cells of $E$. pectinacea as having thicker walls than those of E. Purshii, the latter being adapted to dry and sandy soil. C. B. Weaver (2I) worked upon the anatomy of Andropogon nutans, A. scoparius, A. sorghum, and $A$. sorghum var. halepense. Miss Pammel's studies of Bromus show little development of bulliform cells and a homogeneous mesophyll, in contrast with the prominent bulliform cells of reduced spongy parenchyma and the radial palisade of Weaver's Andropogon and Ball's Eragrostis, both species of dry habitats. Theo. Holm (8) has studied the species of the genera Uniola, Distichlis, Pleuropogon and Leersia. Pammel, Weems, and Lamson-Scribner (II) have called attention not only to the use of anatomical characters of grasses for systematic distinction but to such structures as related to habitat. An interpretation of the above cited morphological facts concerning a number of species of a genus and a comparison of genera with a knowledge of the habitats of these plants would leave no doubt as to the adaptation of species of this family to their habitats.

In general, the anatomy of these leaves of prairie plants resembles that of the plants described in Harshberger's (7) pine barren studies in their development of epidermis and mesophyll features.

Ella Shimek (I6) has described plants of Iowa prairies with some illustrations of leaf characters, in which the leaf structure coincides with the anatomical observations of the present study.

\section{SUMMARY}

The leaves of prairie plants show a xerophytic tendency in their leaf structure, indicated by the specialized palisade tissue, the thick-walled and trichomeless epidermis, the presence of water-storing tissue, and sometimes of trichomes.

The mere presence of these characters is not of primary significance as an indication of xerophytism, but their relative development correlated with other morphological features of the plant such as the extensiveness of the root system.

The upland plants have a thinner epidermis than those of the lowland, and 70 percent of those studied are without trichomes while 75 percent of the upland species have trichomes. 
Of the alluvial basin leaves studied, 50 percent were bifacial while 33 percent of the upland plants have bifacial leaves; $121 / 2$ percent of the alluvial basin plants were centric to subcentric; 50 percent of the upland plants were centric to subcentric.

Iowa State College,

AMEs, Iowa

\section{LITERATURE CITED}

I. Bakke, A. L. Studies on the transpiring power of plants as indicated by the method of standardized hygrometric paper. Journ. Ecol. 2: I45-I73. I9I4.

2. Ball, C. R. An anatomical study of the leaves of Eragrostis. Proc. Iowa Acad. Sci. 4: I40-I4I. I 897 .

3. Bonnier, G. Cultures expérimentales dans les Alpes et les Pyrénées. Rev. Gén. Bot. 2: 5I3-546. I 890 .

4. Clements, E. S. Relation of leaf structure to physical factors. Trans. Amer. Micr. Soc. 26: I9-I02. pls. I-9. I904.

5. Dufour, L. Influence de la lumière sur la forme et la structure des feuilles. Ann. Sci. Nat. VII. Bot. 5: 3II-4I3. pls. 9-I4. I887.

6. Haberlandt, G. Physiologische Pflanzenanatomie. I904.

7. Harshberger, J. W. The vegetation of the New Jersey pine barrens. I9I6.

8. Holm, T. A study of some anatomical characters of North American Gramineae. Bot. Gaz. I6: I66-I7 I, 219-225, 275-28I. pls. I5, 21-24. I89I. I7: 358-362. pl. 2 I. I892.

9. Kearney, T. H. The plant covering of Ocracoke Island. Contr. U. S. Nat. Herb. 5: 26I-3I9.

I0. Lesage, P. Sur les rapports des palisades dans les feuilles avec la transpiration. Compt. Rend. Acad. Sci. (Paris) i 8.

I I. Pammel, L. H., Weems, J. B., and Lamson-Scribner, F. The grasses of Iowa. I899.

12. Pammel (Hansen), E. A comparative study of the leaves of Lolium, Festuca and Bromus. Proc. Iowa Acad. Sci. 4: I26.

I3. Pammel, E., and Sirrine, E. Some anatomical studies of leaves of Sporobolus and Panicum. Proc. Iowa Acad. Sci. 3: I5I. pl. 6, f. I-3. 1896.

I4. Pick, H. Ueber den Einfluss des Lichtes auf die Gestalt und Orientirung der Zellen des Assimilationsgewebes. Bot. Centralbl. II : 400-406, 438-445. pl. 5. I882.

I5. Schimper, A. F. W. Plant geography upon a physiological basis. Engl. Trans. Oxford. I903.

I6. Shimek, E. Ecology of prairie plants. Proc. Iowa Acad. Sci. 22: I2I. I9I4.

I7. Sirrine, E. A study of the leaf anatomy of some species of the genus Bromus. Proc. Iowa Acad. Sci. 4: I I9. pl. 4, f. I; pl. 7, f. 7. I897.

I8. Starr, A. Comparative anatomy of dune plants. Bot. Gaz. 54: 265-305. I9i2.

I9. Solereder, H. Systematic anatomy of the dicotyledons. Eng. Trans. by Boodle, L. A., and Fritsch, F. E. Revised by Scott, D. H. 2 vols. Oxford, I908.

20. Vesque, J., and Viet, C. De l'influence du milieu sur la structure anatomique des végétaux. Ann. Sci. Nat. VI. Bot. I2: I67-I76. I88I.

2I. Weaver, C. B. An anatomical study of the leaves of some species of the genus Andropogon. Proc. Iowa Acad. Sci. 4: I32-I37. pl. I2, I3, I4, I5. 1896. 


\section{EXPLANATION OF PLATES IX-XIV}

The figures were made with the aid of a camera lucida and are magnified approximately 30 diameters.

$E d$, dorsal epidermis; $E v$, ventral epidermis; $P$, palisade parenchyma; $S p$, spongy parenchyma; $V B$, vascular bundle; $b$, bulliform cell; $r$, resin duct; $s$, stomate; $t$, trichome; $c p s$, chlorophyll parenchyma sheath.

Plate IX. Fig. I, Andropogon scoparius; Fig. 2, Bouieloua curtipendula; Fig. 3, Muhlenbergia mexicana; Fig. 4, Leersia oryzoides; Fig. 5, $a$ and b, Polygonum Muhlenbergii; Fig. 6, Anemone cylindrica.

Plate X. Fig. 6a, Baptisia leucantha; Fig. 7, Amorpha canescens; Fig. 8, Ceanothus americanus; Fig. 9, Steironema lanceolata; Fig. I0, Apocynum cannabinum; Fig. II, Asclepias verticillata.

Plate XI. FIG. I2, Mentha arvensis var. canadensis; Fig. I3, Physostegia virginiana; Fig. I4, $a$ and b, Lycopus virginicus; Fig. 15, $a$ and b, Mimulus ringens; Fig. 16, Eryngium yuccaefolium.

Plate XII. FIg. I7, Aster salicifolius; Fig. I8, Helianthus tuberosus; Fig. I9, Helianthus grosseserratus; Fig. 20, Coreopsis palmata; Fig. 21, Solidago graminifolia; Fig. 22, Silphium laciniatum.

Plate XIII. Fig. 23, Solidago serotina; Fig. 24, Artemisia ludoviciana; Fig. 25, Solidago canadensis.

Plate XIV. Fig. 26, Solidago rigida; Fig. 27, Vernonia noveboracensis. 


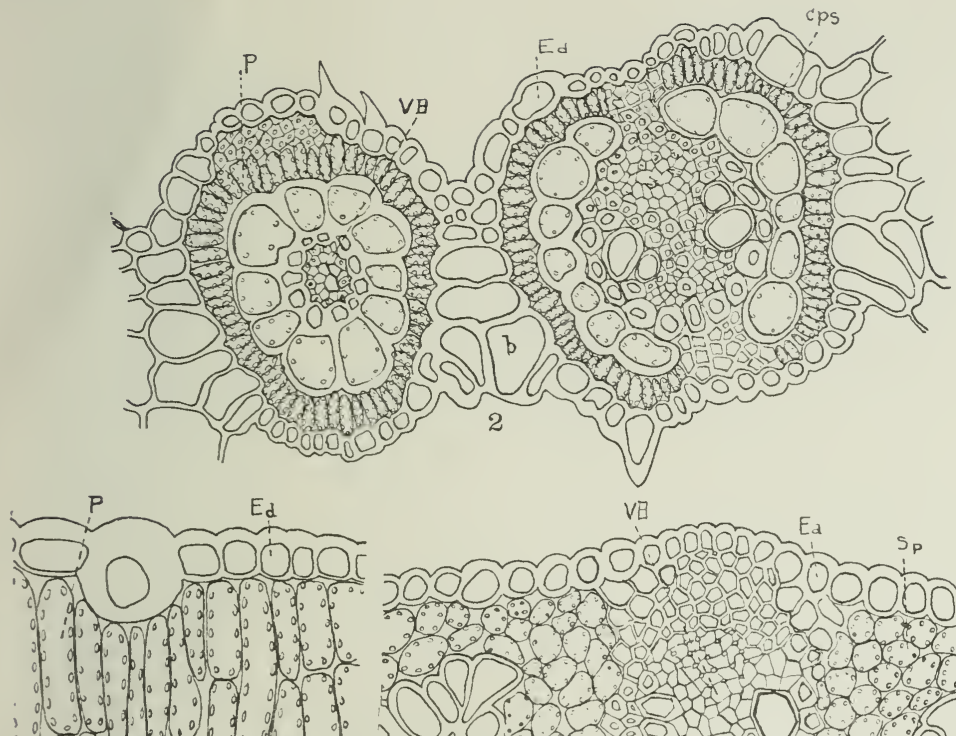

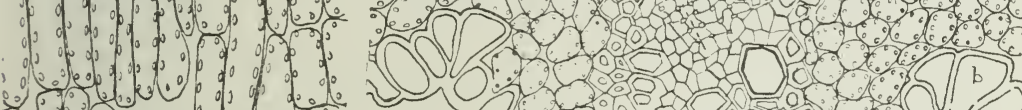

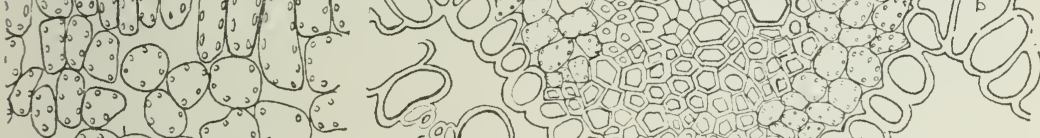

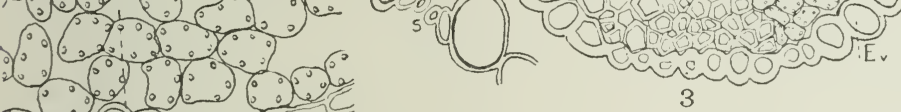
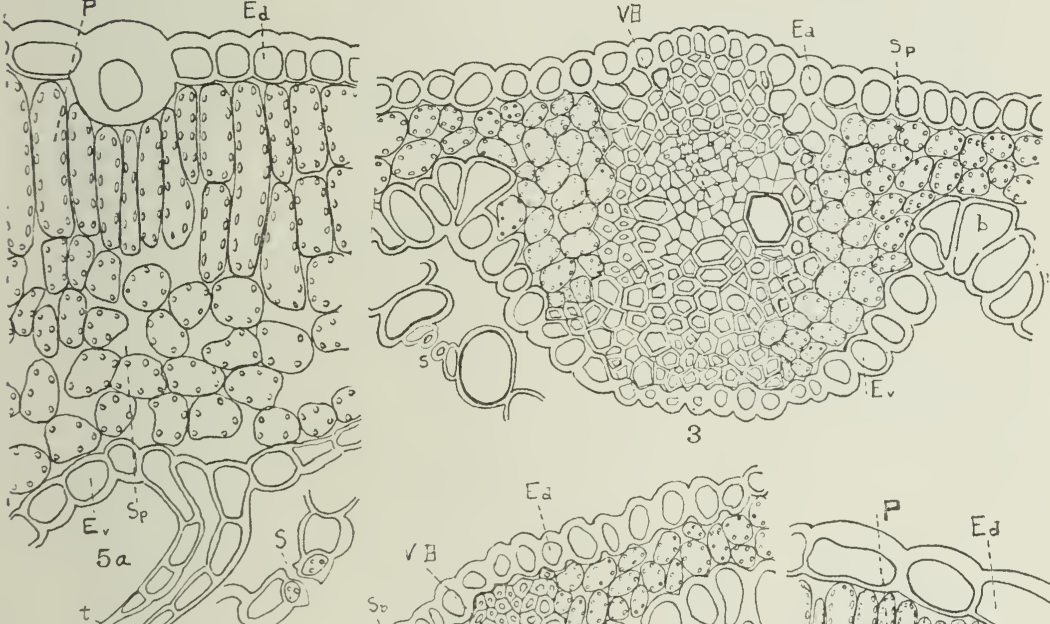

Ea

V.

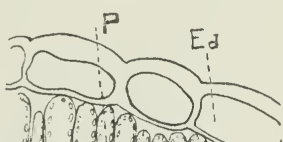

100.6.

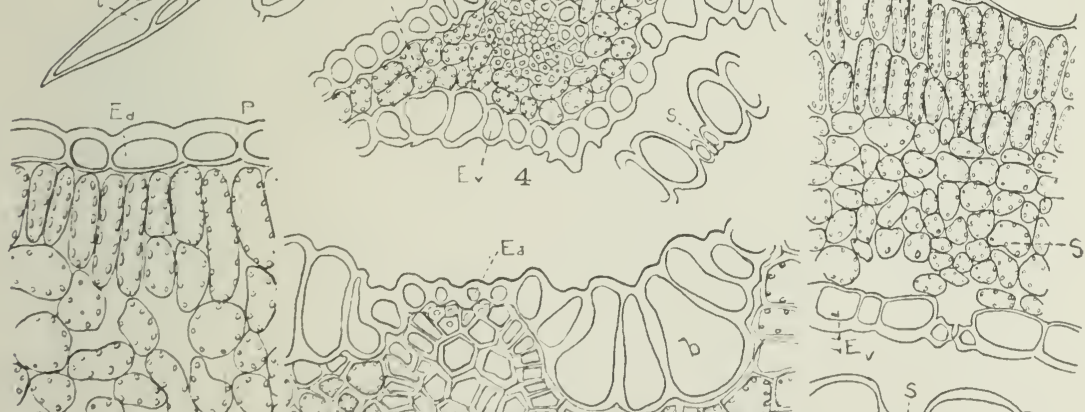

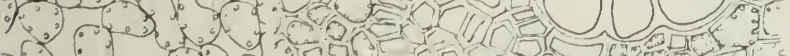

2.

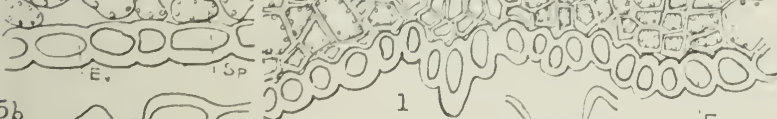

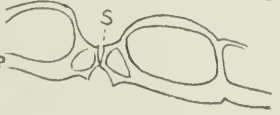

$5 b$

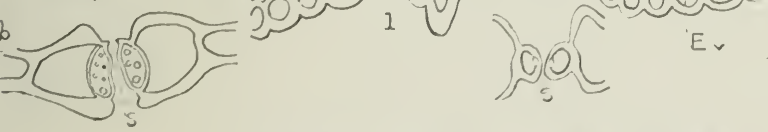

6

Hayden: ECOlOGic foliar ANatomy. 



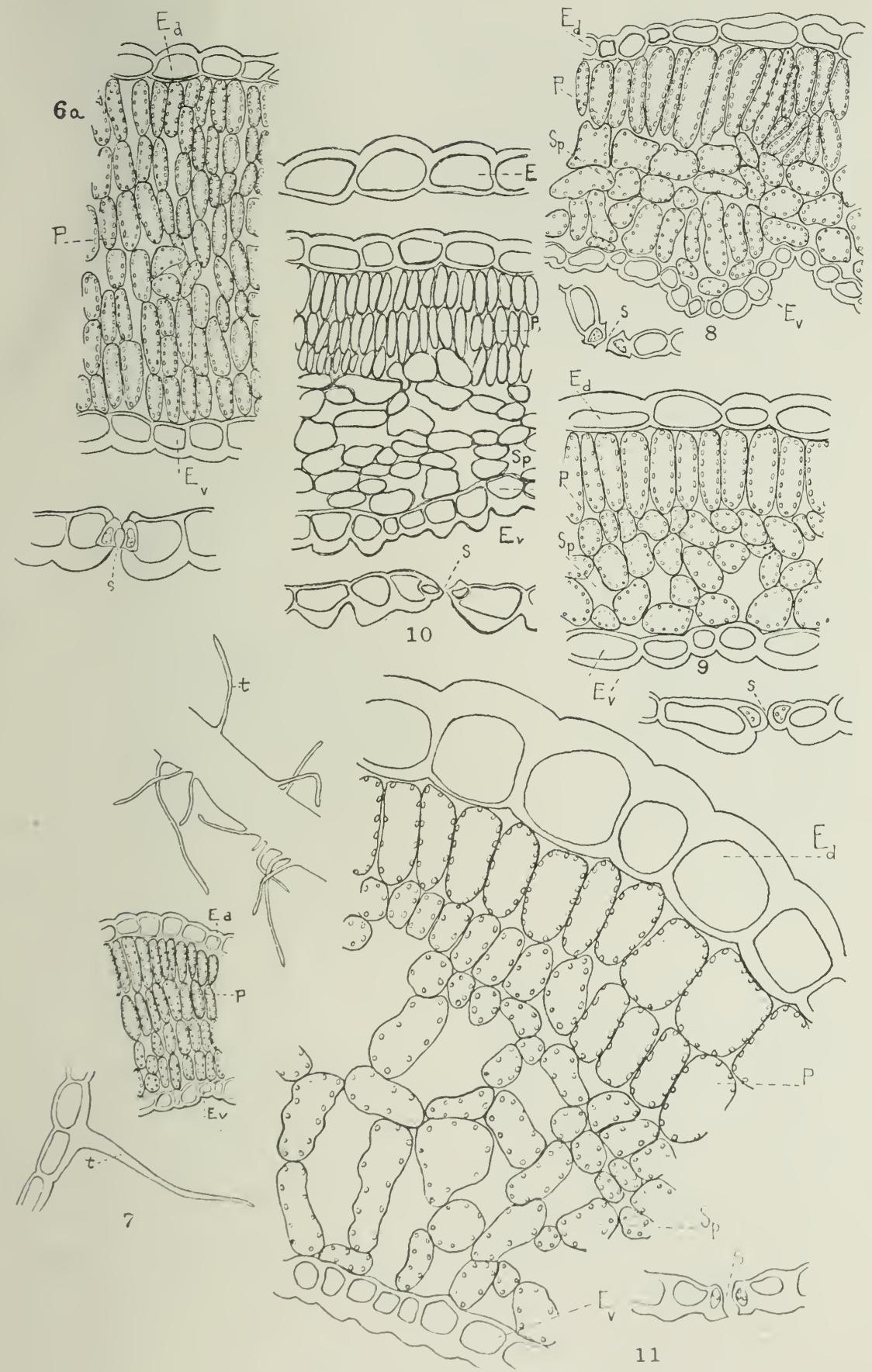

Hayden: Ecologic folmar Anatomy. 


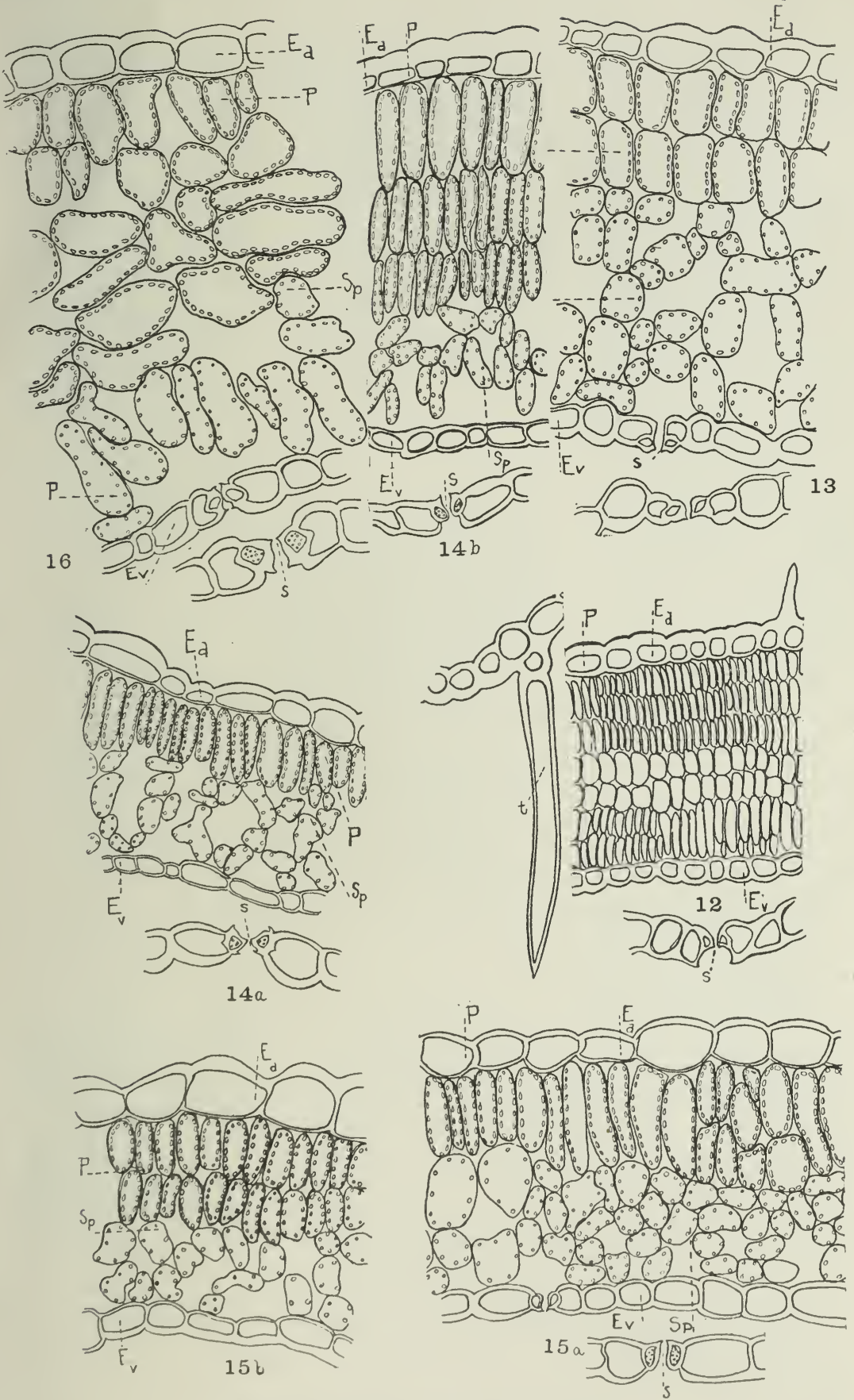

HAyden: Ecologic foliar Anatomy. 


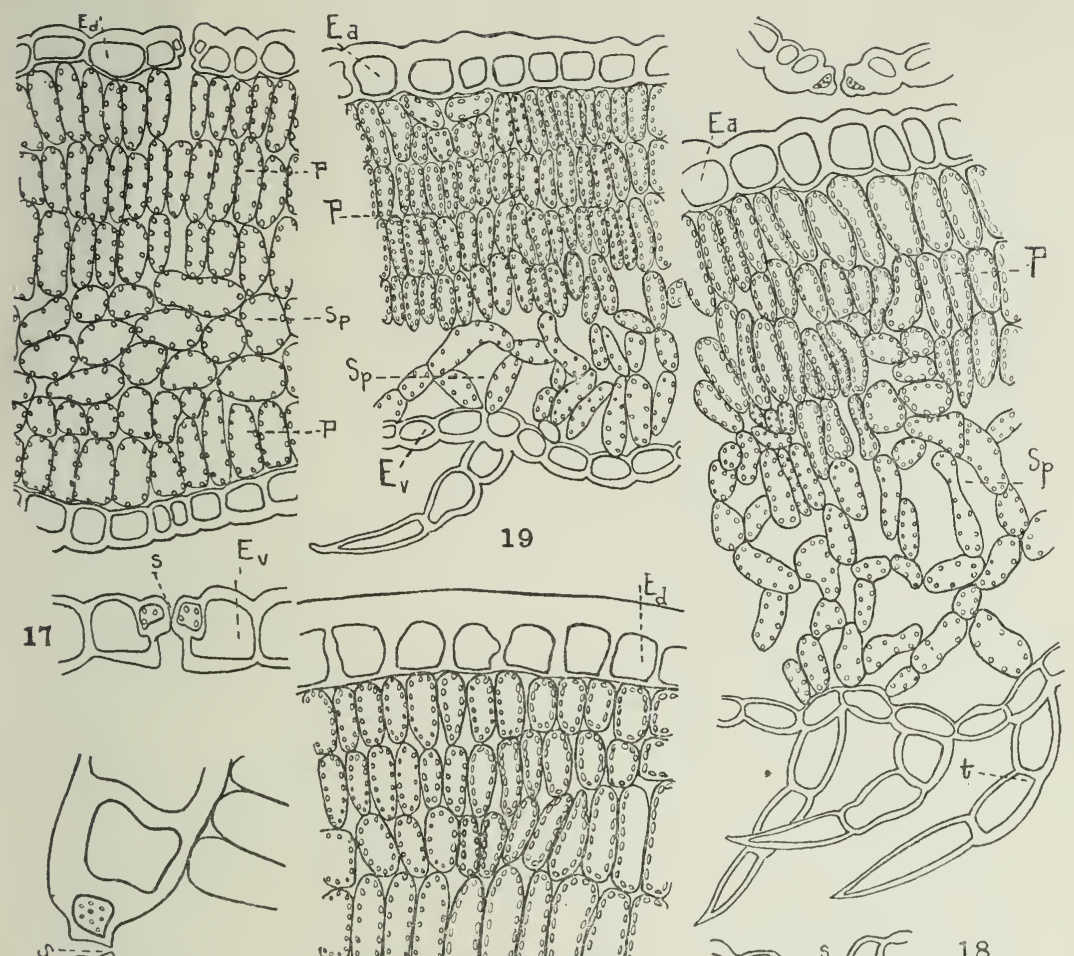

.
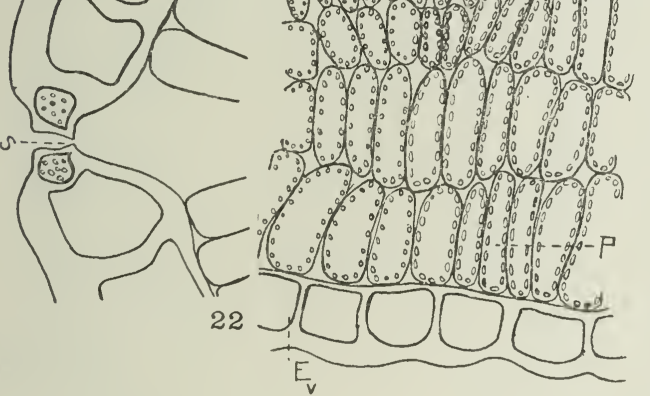

$E_{\mathrm{d}}$

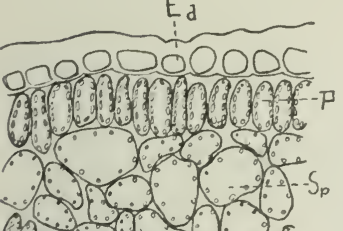
him. simmume
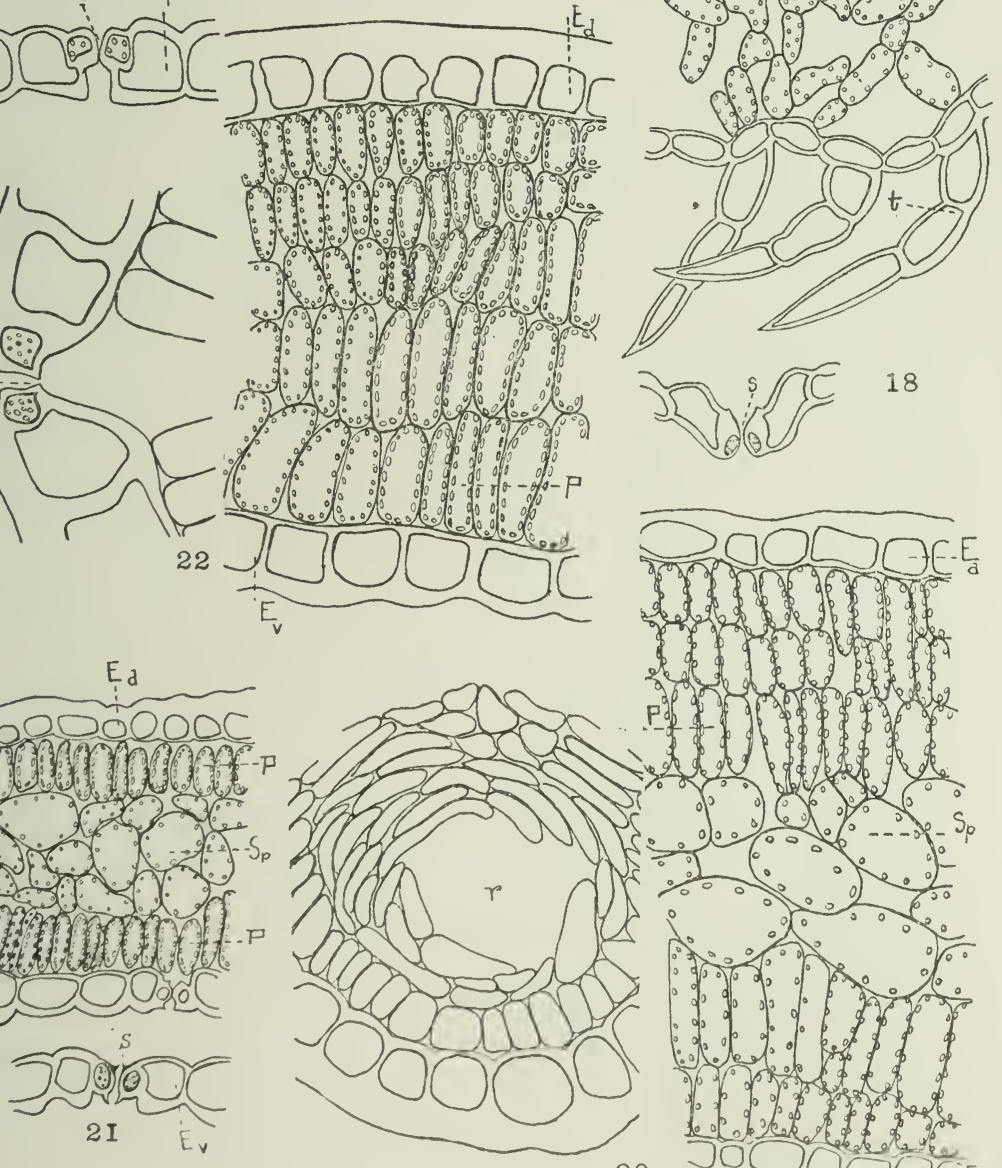

गुण 00 2o

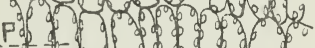
2.

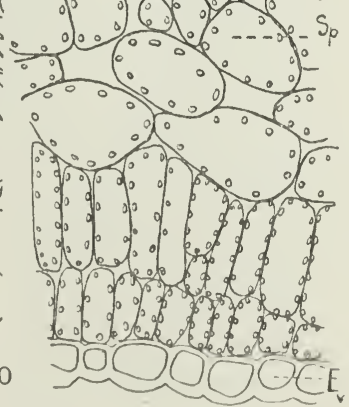

Hayden: Ecologic foliar Anatomy, 



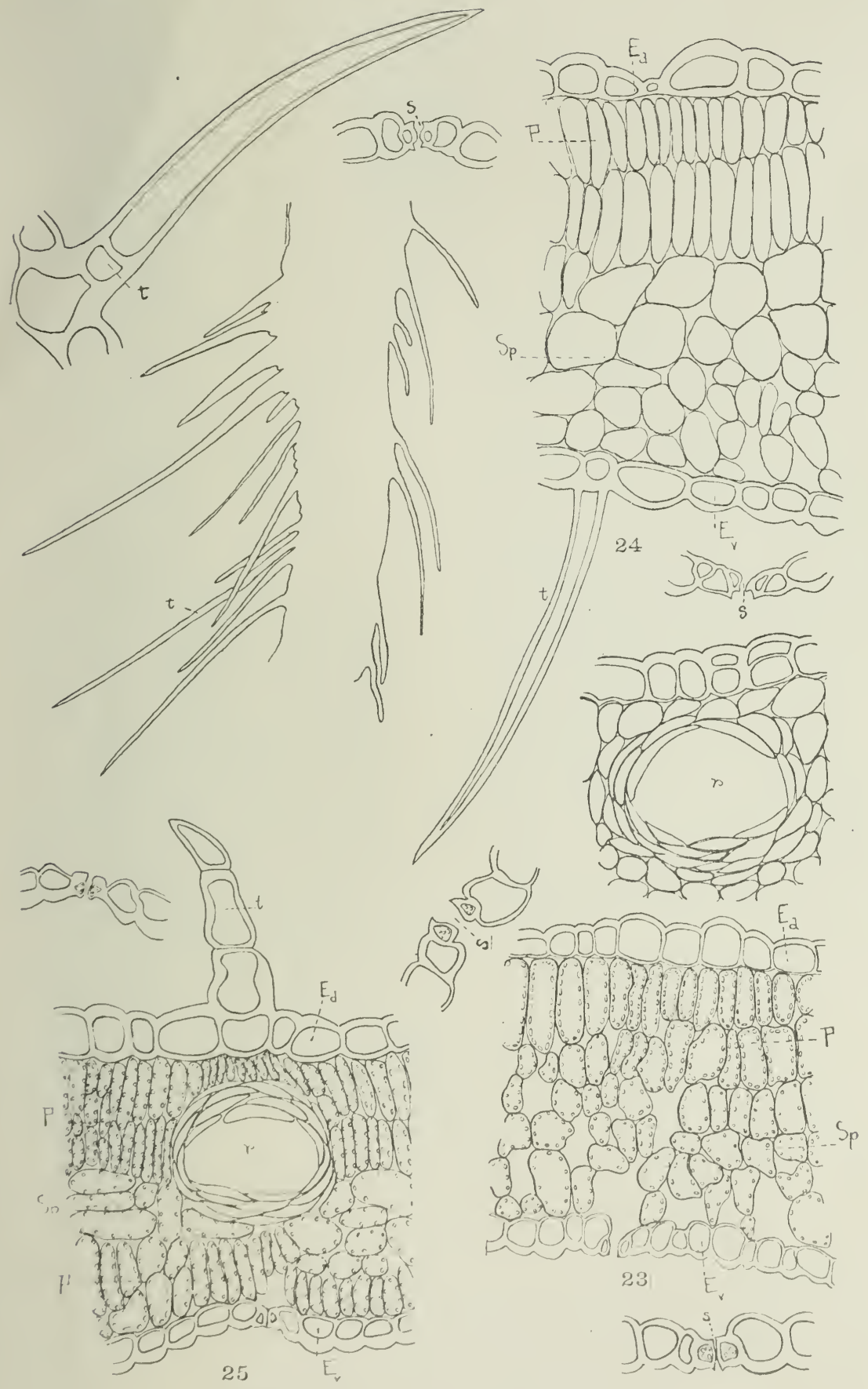

Hayden: ECologic foliar Anatomy. 



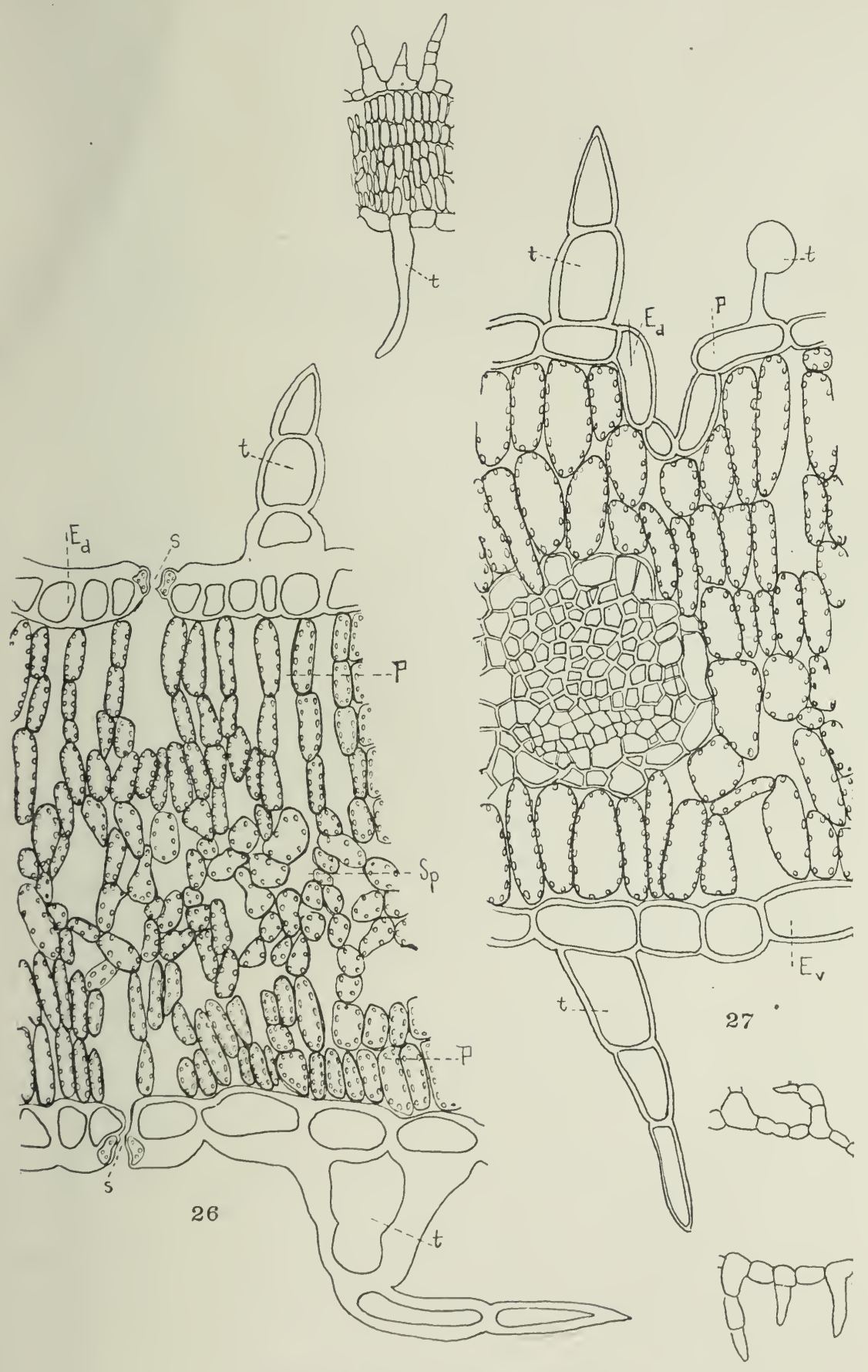

Hayden: Ecologic foliar Anatomy. 

[Reprinted from the American Journal of Botany, 6: 87-I05, March, I9I9.]

\title{
THE ECOLOGIC SUBTERRANEAN ANATOMY OF SOME PLANTS OF A PRAIRIE PROVINCE IN CENTRAL IOWA
}

\author{
Ada Hayden
}

\section{INTRODUCTION}

A survey of the literature pertaining to functional and adaptational features of subterranean organs as related to their morphology shows this subject to have been less investigated than that of leaf structure. Though there has been considerable work done in the field of pure morphology, that too is yet deficient in many respects. Descriptions found in Gray's Manual of Botany (8) and Britton and Brown's Flora (I) have either no reference to subterranean parts or only incomplete ones.

The subterranean organs of prairie plants are of two classes, roots and subterranean stems. Of course all these plants have secondary, $i . e .$, absorbent or collecting roots, but in many plants the subterranean stems are intermediate structures connecting collecting roots with conducting aërial stems and therefore assume the function of primary or main roots.

Prominent subterranean stems are seen in the majority of alluvial basin plants and in modified abbreviated form in the upland plants, especially in the grasses and composites which constitute the majority of the upland plants.

It was the object of this study of subterranean stem and root types $(a)$ to note whether variations were correlated with habitat; $(b)$ to determine whether the stems were equivalent to or advantageous to the root in the economy of the plant.

The functions of subterranean organs are storage, anchorage, absorption, conduction, and propagation. Anchorage in the case of prairie plants may be dismissed, for most of them are low, have a compact habit of growth, and are not particularly subject to uprooting. As to propagation, the fact that subterranean stems have numerous nodal buds while roots have adventitious buds, if any, gives subterranean stems, especially rhizomes, the advantage as propagators. Concerning storage, the root and the subterranean stem seem to be equally well equipped, though this question will be discussed under anatomical structure. 


\section{Methods}

The material was stored in $50 \%$ alcohol, and after free-hand cutting the sections were stained with a solution of water-soluble safranin, followed by haematoxylin, cleared in cedar oil and clove oil, and mounted in Canada balsam. The drawings of the subterranean structures were not made to a single scale because the large size of some of them made this impracticable, and also because of the variability in size, which makes the comparison of the size of the roots and stems of species less important than the relative proportion occupied by the tissues of the roots compared.

\section{HistoricAL}

Some progress has recently been made in classifying subterranean organs; among the valuable contributions are those of Cannon (2), Harshberger (I I), Holm (I3), Yapp (I8), Dauphiné (6), Constantin, Jodin (I5), and Maxwell (I6).

Maxwell (16) reviews the history of the histological study of roots, which before I 865 were studied as masses of tissues and after this period with reference more directly to the origin of organs.

According to Cannon (2), the work of Rimbach, Büsgin, and Friedenfeldt as reviewed by Von Alter (Wurzelstudien, Bot. Zeit. 67: 175. I909) is important because their researches indicate that the root systems of flowering plants may be divided into two groups according to the character of the terminal roots; they are either intensive or extensive. Intensive root systems have fine terminal roots; they are richly branched and occupy smaill soil volume. Extensive root systems have coarse ultimate roots, are not richly branched, and occupy a relatively large soil volume. Cannon describes three main types of root systems found in the desert plants of the southwestern United States: (a) Root systems which extend horizontally from the main axis and lie for their whole course near the surface of the ground. (b) Root systems which are characterized by a strongly developed tap root going down directly to a depth determined in part by the character of the soil, in part by the penetration of the rains, and in part by the character of the root itself. (c) Roots that not only reach widely but penetrate fairly deeply. When the root is of an obligate type the distribution of the species is much restricted, but when it undergoes modification with changed environment the distribution of the species is much less confined.

Yapp (I8) and Scherff ( $\left.I_{7}\right)$, in their marsh studies, note the stratification of subterranean systems as well as the aërial portions of different species.

Holm (I3) reviews a paper of Häckel (Io) on the peculiarities of the grasses of dry climates, among which he distinguishes (a) tuberous and bulbous grasses and (b) tunic grasses. The tuberous and bulbous forms occur only in countries with periodic dry seasons. None have been observed in 
the moist parts of the tropical region. The author does not regard these bulbs or tubers as reservoirs of starch or sugar, as is true of the similar organs of the Liliaceae and Iridaceae. Though they are structurally homologous with these, physiologically they are reservoirs. The author has shown that Poa bulbosa on being cultivated in moist soil almost loses its bulbous character. The second group includes forms in which the bases of the culms and shoots are covered with at least three faded sheaths. These all inhabit dry localities. In those forms which prefer damp or shaded places there is usually one faded sheath present, and even that disappears soon. Straw tunics are distinguished from fiber tunics; in the former the sheath remains complete although faded, in the latter the sheath breaks up into fibers. The function of these tunics is regarded as that of water conservation. Holm has contributed various studies on the morphology of subterranean portions of plants.

\section{Gross Anatomy}

In the alluvial basin region the prairie plants under observation show a prominent development of thickened, elongated rootstocks. The majority of these plants are Gramineae, Cyperaceae, and Compositae, in which this feature is a systematic character. The Cyperaceae are seldom found on the highland, but the upland members of the Compositae and Gramineae, while they retain their rootstock characters, have abbreviated forms. The Gramineae especially show abbreviated subterranean parts in the form of hard bulbous or corm-like thickenings from which the roots radiate, or of short hard rootstocks. Panicum virgatum, which has a wide range of habitat, growing either on upland or lowland, has hard, radially branching, slender, scaly rootstocks which are shorter in the drier upland habitats. Spartina Michauxii, which grows on lowland or in moist upland ravines subject to drought, shows shorter rhizomes on the upland. The Solidagos which frequent the ridges have very abbreviated, hard, corm-like subterranean stems, while those which frequent moist habitats have longer rhizome-like structures. The genus Liatris has a species with short, sheathed corm which grows on the hilltops and a species with an elongated, fibrous-sheathed tuber on the moister slopes. Helianthus grosseserratus has a short, thick rootstock, while II. tuberosus has a long, slender-stemmed tuber. Silphium laciniatum is provided with a deep root. The Compositae are variable, having short tubers, elongated rhizomes, corm-like structures, or tap and fascicled roots, which enable them to thrive in a wide range of habitats and probably account for their great numbers and diversity of forms. Among the Leguminosac are Desmodium illinoense, Amorpha canescens, Lespedeza canadensis, Petalostemum purpureum, and $P$. albidum, which are upland plants with deep, tough roots, usually having long, thick tap roots and somewhat smaller lateral roots. These leguminous plants and others with 
similar root habits show little storage area but have prominent tracheae, which would indicate that they derive their moisture from a lower water table than do their short-rooted neighbors. Liatris shows few tracheae but much storage tissue. Ceanothus has also a deep, branched tap root. The exterior of the cortex of the roots is corky, leathery, fibrous-sheathed, or flaky-deciduous, while the subterranean stems have hard, scaly fibrous or straw sheaths which probably have the ability to hold water by capillarity as well as to prevent evaporation from the inner parts. These scaly coverings of thickened subterranean organs, especially of rhizomes, are prominent in both uplands and alluvial basins. Since conditions of drought are likely to occur frequently and especially in protracted periods during the latter part of the summer, these features are undoubtedly useful as a protection against desiccation. The swamp plants must be able to tolerate not only moisture to the point of saturation but drought as well. The roots of the upland plants may be regarded as of the intensive type, those of the lowlands as of the extensive type.

\section{Minute Anatomy}

The anatomical descriptions of the stems and roots studied have been made under the heads $(a)$ Primary cortex, and $(b)$ Stele, which portions of the stem and root are homologous. These structures show certain prevalent types which may be distinguished in the angiosperms as follows:

Monocotyledons-

Stem: concentric or collateral, endarch bundles.

Root: radial, exarch bundles.

Dicotyledons-

Stem: concentric, endarch bundles.

Root: radial, exarch bundles.

There is great diversity of structure shown by the representatives of different families and individuals thereof, whose morphological and physiological variations are discussed by De Bary, Solereder, Haberlandt, Stevens, Coulter, Barnes, Cowles, and others. Exceptions seem more abundant than cases of conformity to rules at the present status of correlation. Transformations from the original types take place with the secondary thickening process, in numerous instances to such an extent that the original type structures are hardly recognizable. Systematic relations have not been conclusively worked out, yet every species has in some degree established its economy of water relations, the indicators of which, in so far as experiment has proceeded, are shown to be primarily (a) parenchyma (storage and aerenchyma), (b) mechanical tissue, and (c) conductive tissue. The prominence of the latter two seems to indicate xerophytism and that of the first the reverse condition. The relative proportion of these tissues in each individual stem or root has been used as a means of indicating its degree of xerophytism in this study. 
Before applying these tests perhaps the reasons for selecting them should be given. An examination of young water-absorbing roots shows them to have a deep cortex bearing root hairs and a small vascular cylinder with distinctly radial bundles. "In roots, any departures from the typical radial structure of the vascular strands are generally correlated with special environmental conditions, or arise from the necessity of increasing the amount of available conducting tissue" (Haberlandt). In a radial root there is no means of tangential increase, so this increase must take place in a radial direction toward the cortex and results in orienting a cambium which produces concentric layers of phloem and xylem. This is seen to be an advantageous structure in older roots whose function is conduction and not absorption from the cortical layer, for here there is no incoming stream of water to cross the proteid-conducting zone but only a rising central column. It is seen that such an arrangement is also desirable for resistance to strains which in roots are in a longitudinal direction. This solid cylinder gradually develops pith and assumes an annular vascular structure in the stem, from which bundles shoot out into the branches. Hence a root changes from a water-collecting to a water-radiating organ and the pith of the stem serves as a good collecting reservoir; though pith is sometimes absent. The stem, being subject to radial strains, is thus well adapted by its hollow-cylinder mechanical system.

Rhizomes (Haberlandt) which fix the plant in the soil agree with roots in having their mechanical tissues united to form a stout axile tube or a solid central strand; this centralization of the mechanical system is very marked in the rhizomes of grasses, sedges, and rushes, which, accordingly, when regarded from an anatomic-physiological standpoint, approximate more closely to roots than to the aerial stems of which they are the morphological equivalents.

Structural features (Solereder) which vary with the amount of water in the soil and air and with the degree of transpiration on the part of the plant, affecting chiefly the number of vessels and width of lumina, are of minor systematic value.

Kohl observed that certain plants (Mentha aquatica, Thalictrum galeoides, and Menyanthes trifoliata) develop more collenchyma and bast if grown in dry air, $i . e$., under conditions favorable to transpiration, than they would if produced in a moist atmosphere, i.e., with their transpiration reduced. Here it is impossible to state with certainty whether the process is adaptive or self-regulatory. It should, however, be noted that in the case of herbaceous plants growing in a dry atmosphere, or in fact under xerophytic conditions in general, türgor has a smaller mechanical value than usual because the risk of temporary wetting is so great in these circumstances that any decrease in the development of mechanical tissue must be advantageous. In general, there is correlation between the number of water-conducting vessels and the extent of the foliar transpiring surface. 
Jost, by removing the leaves of seedlings of Phaseolus multiflorus, Helianthus annuus, and Vicia Faba, found that the vascular bundles supplying the amputated leaves remained rudimentary. There is evidence of a process of adaptive self-regulation.

Kohl has demonstrated that the water-conducting system may be reduced by growing the plants in a moist atmosphere, and Schenck has demonstrated the reduction of vascular bundles of Cardamine pratensis by growing the terrestrial plant in water. Plants which are naturally amphibious exhibit a similar character.

The endodermal layer has been a subject of considerable experiment and study. In some plants the cells of this layer have thickened inner walls, and in some the walls are of uniform thickness. Schwendener has shown that the endodermis is impermeable except in spots where it acts as side sluices in a system of irrigating canals, the main channels of which are represented by the vessels. Greatly thickened endodermal layers are found in marsh plants which live in places likely to dry up periodically. This is true of some plants growing in dry regions.

Gaseous exchange is slow under aquatic conditions and is accelerated by the presence of air spaces. Aerenchyma is also found in marsh plants subject to submerging.

These facts show that the relative distribution and proportion of mechanical tissue, parenchyma, and conductive cells are of considerable significance with reference to adaptation in the economy of plant tissues.

\section{Description of Subterranean Organs}

\section{Typha latifolia L.}

\section{Typhaceae}

Habitat: Alluvial basin; marsh.

Gross structure: Long, stout, horizontal rootstocks; 6-8 in. deep; soft and spongy, origin from a thick stem base; long, slender; straight roots, at notes, perennial (Plate XV, fig. $d$ ).

Histology of rhizome (Plate XVI, fig. I):

Primary cortex: Radius of cortical area $1 / 2$ radius of rhizome; hypodermis, thinwalled parenchyma; next a zone of rounded-compact parenchyma in which vascular bundles are originating; zone of aerenchyma in which vascular bundles have enlarged; bundles surrounded by woody sheath. Endodermis pronounced, with thick inner wall.

Stele: Composed of one row of large, woody bundles surrounding the pith cylinder of thin-walled aerenchyma, among which are scattered smaller vascular bundles with compact, thick, woody sheath.

Summary: Air space prominent; parenchyma well developed; vascular tissue fairly abundant; slight mechanical tissue, found only at sheath for bundles; vascular strands act as mechanical tissue in cortex.

Histology of root (Plate XVI, fig. 2):

Primary cortex: Composed of 4 -sided to oval parenchyma cells; air space small; no mechanical tissue.

Stele: Radius $4 / 5$ that of the root; conducting vessels fairly prominent, surrounded by parenchyma. 
Phragmites communis Trin.

\section{Gramineae}

Habitat: Alluvial basin; edge of water, wet soil.

Gross structure: Long, creeping rhizome, thick, soft and spongy; scales at nodes prominent; clusters of roots emerging from nodes bearing fine secondary hair-like roots; rhizomes branch in several directions and at several levels; perennial (Plate XV, fig. b).

Histology of rhizome (Plate XVII, fig. I):

Primary cortex: Radius equal to I/2 radius of rhizome; epidermal cells small, thick-walled; hypodermis of thin collenchyma; parenchyma large-celled, hexangular, forming arches around large oval air cavities in a ring within cortical cylinder.

Stele: Hypodermis, 3 rows of collenchyma; main portion of vascular cylinder composed of large thin-walled parenchyma surrounding rows of alternately arranged vascular bundles; vascular bundles sheathed by wood fibers; one row of small bundles where arches of cortical parenchyma join vascular cylinder.

Summary: Rhizome characterized by prominent thin-walled cortical cylinder; mechanical tissue reduced; vascular bundles few.

Histology of root (Plate XVII, fig. 2):

Primary cortex; Radius 5/7 of root radius; hypodermis, 3 rows thin collenchyma; parenchyma of large oblong cells with long axes radially placed; large elliptical air spaces; endodermis prominent, with thick outer wall.

Stele: Composed of small thin-walled parenchyma cells with a ring of young radial vascular bundles in which the exarch arrangement of metaxylem and protoxylem is very distinct.

Summary: Young root composed almost entirely of thin-walled, loosely arranged parenchyma with prominent air space, only a trace of mechanical tissue.

\section{Spartina Michauxiana Hitchc.}

Habitat: Alluvial basin; wet ground; sometimes fairly dry locations.

Gross structure: Creeping radial rhizome; long, tough, hard; scaly; springs from a short, condensed base; perennial (Plate XV, fig. $h$ ):

Histology of rhizome (Plate XVIII, fig. I):

Primary cortex: Radial depth $3 / 7$ radius of rhizome; epidermis small-celled, thick, walled; hypodermis, 7 rows of collenchyma in which occasional small vascular bundles are embedded; clusters of compact, round parenchyma cells alternating with large air spaces constitute the inner arc of the cortex; endodermis thickwalled.

Stele: Sclerenchyma of 6 rows borders outer margin and hollow center of this cylinder; vascular bundles numerous, large, with prominent sheath of wood fibers; pith parenchyma relatively thick-walled; only a few cells of pith between bundles.

Summary: Parenchyma and air space reduced; mechanical tissue prominent; vascular bundles numerous, large.

Panicum virgatum $\mathrm{L}$.

Habitat: Alluvial basin; low, wet soil; sometimes moist; dry upland.

Gross structure: Plant tufted, with long, creeping rhizomes; scaly, hard and tough perennial.

Histology of rhizome (Plate XVIII, fig. 2):

Primary cortex: Radius 2/9 that of rhizome; epidermal cells 4-sided, thick-walled, small; hypodermis, 7-8 rows of thick collenchyma; inner half of cortex composed of clusters of thin-walled, compact parenchyma alternating with large air spaces.

Stele: Vascular bundles large, numerous, surrounded by thick sheaths of sclerenchyma; pith parenchyma of 2-3 rows separating the bundles; bands of scleren- 
chyma 3-4 cells deep bound the perimeter of the vascular cylinder and surround the hollow center.

Summary: Parenchyma poorly developed; air space small; mechanical tissue prominent; vascular bundles large, strongly sheathed.

Scirpus fluviatilis (Torr.) Gray.

\section{Cyperaceae}

Habitat: Alluvial basin; swamps.

Gross structure: Rhizome elongated, terminating in tuber-like swellings; radial growth; moderately thick; hard tuberous tip but spongy root-stalk; horizontal, descending; perennial (Plate XV, fig. $c$ ).

Histology of rhizome (Plate XIX, fig. 3):

Primary cortex: Radius $\mathrm{I} / 2$ that of the rhizome; thin-walled, angled to oval parenchyma cells form a band I/5 the depth of the cortex and send down rays to the vascular cylinder, forming arches around the large air spaces; endodermis cells distinct, of uniform thickness.

Stele: Just inside the endodermis one row of concentric vascular bundles strongly sheathed with wood fibers; woody sheathed bundles scattered through the parenchyma; parenchyma compact; thin-walled.

Summary: Air cavities prominent in cortex; parenchyma thin-walled; vascular bundles numerous; parenchyma fairly prominent in central cylinder.

Scirpus validus Vahl.

Habitat: Alluvial basin; margin of pond.

Gross structure: Rhizome stout, scaly; horizontal; linear extension; cortex soft and absorbent; vascular cylinder hard and flinty; fringes of slender roots with secondary hair-like branches radiate from the short nodes, appearing continuous not clustered; perennial (Plate XV, fig. $g$ ).

Histology of rhizome:

Primary cortex: Radius I/ 3 that of the rhizome; air space prominent; parenchyma cells round, with 5-6 spoke-like, short cellular flanges forming a characteristic network; endodermis prominent with thick inner walls.

Stele: Solid; pith parenchyma cells round to oval, rather thick-walled; concentric bundles numerous around the outer perimeter of cylinder, but larger and fewer toward center; bundles thickly sheathed by centripetal arc of bast.

Summary: Aerenchyma prominent; this type of cell structure not only provides ample air space but insures mechanical strength; vascular tissue prominent.

Iris versicolor $\mathrm{L}$.

\section{Iridaceae}

Habitat: Alluvial basin; margin of pond, swamp.

Gross structure: Rhizome thick, relatively short; tuberous swellings; horizontal; linear extension; roots slender, vertically descending, clustered at nodes; fine secondary branches; perennial (Plate XV, fig. $e$ ).

Histology of rhizome (Plate XIX, fig. I):

Primary cortex: Radius I/ 4 that of rhizome; 3 rows hypodermal mechanical tissue; a similar band of angular cells with slightly thickened walls bordering the inner arc of cortex; aerenchyma a hexangular network; endodermis thick-walled on inner surface.

Stele: Pith parenchyma thin-walled, compact, forming a small cylinder in center not entered by bundles; vascular bundles concentric, numerous around perimeter of cylinder, farther a part but larger toward center; woody sheath prominent.

Summary: Cortex with prominent aerenchyma; vascular bundles strongly reinforced. Histology of root (Plate XIX, fig. 2):

Primary cortex: Radius $5 / 6$ radius of root; hypodermis, $2-3$ rows of collenchyma; 
parenchyma thin-walled, compact, with oval areas filled with very large parenchyma cells, 6-8 times the size of the round parenchyma (these areas show signs of breaking up and will probably give rise to air cavities); endodermis with thickened inner wall.

Stele: Parenchyma of small angular cells; bundles radial; a ring of large protoxylem cells lying within radial strands of metaxylem.

Summary: Mechanical tissue undeveloped; parenchyma prominent; tracheal vessels large.

Polygonum Muhlenbergii (Meisn.) Wats.

\section{Polygonaceae}

Habitat: Alluvial basin; muddy or dry places, rarely in shallow water.

Gross structure: Root thick, descending, tough, smooth; rootstocks branching; scaly, branching from root at different levels; horizontal, radial extension; perennial (Plate $\mathrm{XV}$, fig. $a$ ).

Histology of rhizome (Plate XX, fig. I):

Primary cortex: Depth I/6 radius of rhizome, epidermis thin-walled; rectangular cells; hypodermis, several rows of cork; aerenchyma occupies $9 / 10$ of cortical space.

Stele: I/ 6 radius of rhizome; bundles collateral; bast forming a slender zone bordering phloem; phloem cells large, 6-sided; xylem with large tracheae; wood parenchyma 4- to 6-sided, compact, thick-walled.

Pith: Depth 2/3 radius of rhizome; homogeneous aerenchyma.

Summary: Vascular cylinder forming a narrow, compact zone; remainder of stem composed of aerenchyma.

Histology of root (Plate XX, fig. 2):

Primary cortex: Depth I/4 radius of rhizome; hypodermal cork fills I/5 of cortical area; large-celled, thin-walled parenchyma fills $4 / 5$ cortical area; endodermis not distinct.

Stele: Collateral bundles; cone-shaped rays of old phloem surrounded by clusters of sclerenchyma extend into the cortical parenchyma, young phloem of rectangular cells adjacent to cambium; xylem forms a solid, pithless cylinder of large open tracheae and small, thick-walled, 4- to 6-sided wood parenchyma; the exarch character of bundle is shown in the small primary cylinder.

Summary: Parenchyma of cortex thin-walled with thick protective layer of cork; little mechanical tissue in cortex; relatively thick, compact wood parenchyma cells form a solid cylinder.

Ranunculus delphinifolius Torr.

\section{Ranunculaceae}

Habitat: Ponds, rooting in mud; stems and leaves floating.

Gross structure: Slender, fascicled roots; succulent; perennial.

Histology of root (Plate XX, fig. 3):

Primary cortex: Depth $4 / 5$ radius of root; epidermal walls slightly thicker than walls of parenchyma; parenchyma cells large, oval to round, thin-walled, spongy; air cavities at intervals, endodermis walls of uniform thickness.

Stele: Vascular bundles radial; protoxylem and metaxylem distinct; tracheal tubes small.

Summary: Parenchyma prominent, thin-walled; vascular tissue poorly developed; mechanical tissue absent.

Heuchera americana L.

\section{Saxifragaceae}

Habitat: Moist to dry slopes; upland.

Gross structure: Thick, irregularly branched, tough rhizome with small secondary roots; perennial. 
Histology of rhizome (Plate XXI):

Primary cortex: Depth I/5 radius of root; hypodermis of thin-walled cork cells occupying I/6 cortex; thick-walled parenchyma forms a band around phloem; endodermis not distinct.

Stele: Collateral bundles; phloem cells 4- to 6-sided; 3-4 strands of xylem extend from the center of the root radially outward, alternating with broad radii of thin-walled oval to square parenchyma cells.

Summary: Parenchyma prominent; mechanical tissue undeveloped; tracheal tissue proportionally small; cork well developed.

Potentilla arguta Pursh.

\section{Rosaceae}

Habitat: Dry, rocky, gravelly or alluvial soil.

Gross structure: Root tap, fibrous; thick, hard, tough; perennial.

Histology of root (Plate XXII, fig. I):

Primary cortex: Depth I/6 radius of root; cork hypodermis, thick-walled, occupies I/2 of cortex; thick-walled, large-celled, angular parenchyma.

Stele: Radial bundles separated by broad rows of oval-celled parenchyma pith rays which radiate from the center of the root, forming fan-shaped terminal expansions the edges of which extend around the phloem; phloem thin-walled; 4- to 6-sided; xylem in several annular rings; wood parenchyma thick-walled; wood fibers are scattered among the wood parenchyma and form solid rings at termination of yearly growth; tracheae large.

Summary: Protective cork well developed; tracheae large and numerous; mechanical tissue in form of wood fibers prominent.

Petalostemum candidum Michx.

\section{Leguminosae}

Habitat: Dry prairie slopes; near base of hill commonly, while $P$. purpureum occupies ridges.

Gross structure: Root thick, tough; deep tap with prominent secondary roots; tubercled; perennial.

Histology of root (Plate XXII, fig. 2):

Primary cortex: Depth I/6 radius of root; cork hypoderm occupies I/4 of cortex; parenchyma large, angular, fairly thick-walled cells; endodermis not distinct.

Stele: Bundles collateral; clusters of bast lie within the older, and around the young, phloem; these tissues are enclosed by wood rays which pass as radii from the center of the root toward the bark, joining in arches around phloem; xylem with irregular clusters of large tracheae; few small wood parenchyma cells; compact, small wood fibers prominent.

Summary: Cork prominent; parenchyma little; mechanical tissue in form of bast and wood fibers, forming a tough, compact root.

Baptisia leucantha $\mathrm{T}$. and $\mathrm{G}$.

Habitat: Alluvial basin; moist, subject to drought; perennial.

Gross structure: Long, thick tap root with horizontal surface, fleshy branches; tough; tubercled; perennial.

Histology of root (Plate XXIII, fig. I):

Primary cortex: Depth $\mathrm{I} / 2$ radius of root; thin band hypodermal cork; large ovalcelled starch parenchyma with scattered clusters of bast cells; endodermis not distinct.

Stele: Radial bundles; several concentric zones of bast cells laid down in clusters bordering the new phloem and lying within and around the older phloem; broad rows of wood rays of long parenchyma cells extending radially into cortex, 
spreading in fan-shaped areas of parenchyma; tracheae large, prominent; wood fibers conspicuous among wood parenchyma.

Summary: Cortex thick; mechanical tissue prominent; tracheae large, numerous; compact.

Desmodium illinoense Gray.

Habitat: Slopes; moist to dry.

Gross structure: Thick tap fibrous root; branched, tough; tubercled; perennial.

Histology of root:

Primary cortex: Depth $\mathrm{I} / 6$ radius of root; narrow band of hypodermal cork; parenchyma thin-walled.

Stele: Radial bundle; wide rows of long, rectangular cells form wood rays which extend through xylem radially to bark where they form arches around phloem; annual rings prominent; wood parenchyma little; wood fibers abundant; tracheae large but few; large protoxylem and smaller metaxylem tissues of the primary xylem show the exarch character of the bundle.

Summary: Small cortex; prominent stele with much mechanical tissue in form of wood fibers; wood rays prominent; tracheae not conspicuous; compact.

Viola pedata L.

\section{Violaceae}

Habitat: Hill crests and slopes; dry, gravelly soil.

Gross structure: Rootstock short; erect; not scaly.

Histology of rhizome (Plate XXV, fig. I):

Primary cortex: Depth I/4 radius of root; hypodermal cork 2 or 3 rows; parenchyma large-celled, thin-walled; endodermis not distinct.

Stele: Vascular bundles distinct; collateral; separated by parenchyma rays which extend into the large pith cylinder; tracheae numerous, small; wood parenchyma thin-walled; pith parenchyma large-celled, round to oval; fairly compact.

Summary: Parenchyma prominent; mechanical tissue absent; tracheae small, numerous.

Gentiana puberula Michx.

\section{Gentianaceae}

Habitat: Moist slopes, upland mostly.

Gross structure: Slender rhizome bearing fascicles of relatively thickened roots.

Histology of root (Plate XXIII, fig. 2):

Primary cortex: Depth $\mathrm{I} / 2$ radius of root; epidermal cells small, rectangular, thinwalled; 2-3 rows hypodermal collenchyma; large roundish parenchyma cells, fairly compact; endodermis not distinct.

Stele: Radial bundles, scattered clusters of phloem surrounded by large parenchyma cells; vascular cylinder small; tracheids numerous; remains of primary xylem show exarch character of primary bundle.

Summary: Parenchyma prominent, tracheae few; mechanical tissue absent.

A sclepias verticillata $\mathrm{L}$.

\section{Asclepiadaceae}

Habitat: Alluvial basin; low prairie, moist soil.

Gross structure: Slender, radially extensive rhizome, bearing fascicles of thickened roots.

Histology of rhizome (Plate XXII, fig. 3):

Primary cortex: Depth $\mathrm{I} / 4$ radius of rhizome; thick-walled, oval-celled parenchyma; endodermis not distinct.

Stele: Collateral bundles; phloem zone thin, unprotected, cells more or less crushed; xylem with few large tracheae; compact network of wood parenchyma; 
small area of large-celled pith parenchyma into which project the remnants of the endarch xylem.

Summary: Parenchyma prominent; cortex relatively thick; mechanical tissue absent; tracheae few.

Monarda fistulosa L.

\section{Labiatae}

Habitat: Moist to dry slopes.

Gross structure: Elongated, slender, radially extensive rhizome, cross section square. Histology of rhizome (Plate XXIV, fig. I):

Primary cortex: Depth I/4 radius of cylinder; epidermis of rectangular cells with uniformly thickened walls; hypodermal clusters of collenchyma cells in corners of square stem; parenchyma cells round, thin-walled; endodermis thin-walled.

Stele: Collateral bundles; vascular band very thin; 6-sided phloem cells protected by collenchyma; tracheae few; wood parenchyma small-celled; band of collenchyma separates xylem from pith; pith parenchyma of large, round, thin-walled cells.

Summary: Parenchyma prominent; mechanical tissue sparse; tracheae few.

Vernonia fasciculata Michx.

\section{Compositae}

Habitat: Alluvial basin; low wet ground.

Gross structure: Radially elongated, extensive rhizome with clusters of thick fascicled roots.

Histology of rhizome (Plate. XXVII, fig. I):

Primary cortex: Depth $\mathrm{I} / 2$ radius of vascular cylinder; collateral bundles; epidermis of rectangular, uniformly thickened cells; hypodermis, 2-3 rows collenchyma; aerenchyma with branched sclerids at intervals; endodermis thin-walled.

Stele: Collateral bundles; phloem capped with clusters of bast; xylem fascicles separated by thick strands of rectangular-celled wood rays; tracheae few; wood parenchyma thick-walled, compact; wood fibers present; primary endarch bundle distinct; pith aerenchyma with scattered sclerids.

Summary: Aerenchyma prominent; tracheae inconspicuous; mechanical tissue fairly well developed.

Histology of root (Plate XXVII, fig. 2):

Primary cortex: Depth $5 / 6$ of root; epidermis uniformly thickened; aerenchyma fills most of cortical space; endodermis thin-walled.

Stele: Radial bundles; small area of pith in center; tracheae few.

Summary: Aerenchyma prominent; cortex deep; vascular tissue limited.

Aster azureus Lindl.

Habitat: Hill crests and slopes.

Gross structure: Abbreviated rhizome, hard; clusters of roots form a thick fringe along the sides.

Histology of rhizome (Plate XXVI, fig. 2):

Primary cortex: Depth I/7 radius of root; epidermis with horny, cuticularized edge; 3-4 rows hypodermal cork; zone of elongated collenchyma cells.

Stele: Bundles radial; thin-walled parenchyma bearing glands surrounds the phloem ring; bundles tipped with bast; xylem strands appear branched; traversed by annular rings of thin parenchyma; wood fibers strengthen xylem; broad wood rays of elongated parenchyma cells prominent; pith of large, rather thick-walled cells; primary endarch xylem distinct.

Summary: Mechanical tissue fairly prominent; xylem compact.

Artemisia ludoviciana (Nutt.) Riddell.

Habitat: Hillsides. 
Gross structure: Slender, hard rhizome with clusters of filamentous roots.

Histology of rhizome (Plate XXIV, fig. 2):

Primary cortex: Depth I/4 radius of root; cork 4 rows; parenchyma compact.

Stele: Bundles radial, distinct; phloem protected by patches of bast; vessels few; wood parenchyma cells large; bast sheath prominent; pith parenchyma compact.

Summary: Parenchyma well developed but compact; mechanical tissue conspicuous around bundle; xylem tissue sparse.

Antennaria plantaginifolia (L.) Richards.

Habitat: Dry hill crests and slopes.

Gross structure: Slender, radially extensive rhizomes with fringes of slender roots at their nodes.

Histology of rhizome (Plate XXVI, fig. I):

Primary cortex: Depth I/4 of radius of root; cork I/4 of cortex; parenchyma thinwalled, rectangular; endodermis thin-walled.

Stele: Collateral bundles; phloem unprotected, rectangular cells; thick parenchyma rays separate the bundles; xylem with annular rings marked by layers of wood parenchyma at beginning of ring and thick-walled wood fibers at end; pith parenchyma large-celled, rather spongy.

Summary: Cork well developed; mechanical tissue in form of wood fibers prominent. Liatris squarrosa Willd.

Habitat: Slopes, rather dry.

Gross structure: Stem corm-like, hard, flinty; somewhat scaly on surface; bears clusters of small filamentous roots.

Histology of corm (Plate XXVIII, fig. 2):

Primary cortex: Depth I /6 radius of corm; cork I/ 7 of cortex; cortical parenchyma of brick-like cells among which are a few sclerids; resin ducts present, bordered by 2 rows of thin parenchyma cells; endodermis not distinct.

Stele: Collateral bundles; clusters of sclerenchyma cells arranged around the perimeter of the phloem strands; parenchyma thin-walled; xylem in a series of clusters of annular growth; clusters of wood parenchyma and tracheae formed in spring; wood fibers formed in fall; xylem surrounded by fairly thick-walled, elongated parenchyma cells; resin ducts numerous throughout parenchyma; central pith of roundish cells.

Summary: Mechanical tissue prominent; resin ducts conspicuous; parenchyma compact.

Solidago canadensis L.

Habitat: Moist slopes; sometimes dry places.

Gross structure: Abbreviated rhizome with slender clusters of short roots.

Histology of rhizome:

Primary cortex: Depth $\mathrm{I} / 6$ radius of rhizome; hypodermis of mechanical cells; parenchyma rather thick-walled; endodermis not distinct.

Stele: Collateral bundles; points of bast above tips of phloem; xylem fascicles branched outside of the second annular ring; broad bands of wood parenchyma cells separate the bundles; zones of parenchyma cells are left in spring growth; wood fibers appear in bands in fall growth.

Summary: Mechanical tissue prominent; tracheae fairly large.

Histology of root:

Primary cortex: Depth $\mathrm{I} / 2$ radius of root; thick band collenchyma; parenchyma fairly thick-walled; endodermal walls not thickened.

Stele: Radial bundles show exarch arrangement of primary xylem; mechanical tissue fills center of cylinder; tracheae large.

Summary: Cortex deep; conspicuous mechanical tissue; large tracheae. 
Habitat: Dry to moist slopes.

Gross structure: Tuber-like rhizome; rather short; radial extension; bears clusters of small roots.

Histology of rhizome (Plate XXV, fig. 2):

Primary cortex: Depth I/9 radius rhizome; hypodermal collenchyma; scattered sclerenchyma among the elongated parenchyma; endodermis walls of uniform thickness.

Stele: Collateral bundles; xylem fascicles branched above the first annual ring ; broad rows of rectangular-formed wood rays separating the bundles or branches thereof; tracheae numerous; wood fibers prominent; primary endarch xylem distinct; pith parenchyma cells hexangular.

Summary: Mechanical tissue prominent; structure of stem compact.

Lepachys pinnata (Vent.) T. \& G.

Habitat: Slopes; moist to dry.

Gross structure: Abbreviated rhizome; hard; clusters of slender roots.

Histology of rhizome (Plate XXVIII, fig. I):

Primary cortex: Depth I/ 6 radius of rhizome; parenchyma with clusters of sclerenchyma; endodermis not distinct.

Stele: Collateral bundles; xylem fascicles branched; separated radially and sometimes transversely by wood rays of parenchyma; tracheae few, small; wood parenchyma prominent; pith parenchyma with clusters of sclerids scattered through it.

Summary: Mechanical tissue abundant; tracheae small, few; parenchyma rays conspicuous.

Histology of root:

Primary cortex: Depth $\mathrm{I} / 2$ radius root; parenchyma with sclerenchyma cells scattered through; endodermis not distinct.

Stele: Tracheae prominent; wood fibers abundant.

Summary: Mechanical tissue prominent; cortex deep.

Helianthus tuberosus L.

Habitat: Moist slopes.

Gross structure: Slender, radially extensive rhizomes; tuberous.

Histology of rhizome (Plate XXVII, fig. 3):

Primary cortex: Depth I/4 radius of root; hypodermis of collenchyma; parenchyma large-celled, loose; resin glands scattered through parenchyma; endodermis not distinct.

Stele: Collateral bundles; phloem tipped with patches of sclerenchyma; tracheae few; woody parenchyma sparse, rather thick-walled; pith parenchyma of large, round cells, loose; resin glands scattered among pith.

Summary: Parenchyma prominent; mechanical tissue sparse.

\section{Analysis of the Anatomy of Subterranean Organs}

Of the twenty-six subterranean organs studied, fiften were upland plants and eleven were plants of the alluvial basin.

Alluvial basin species: Typha latifolia, Phragmites communis, Spartina Michauxii, Panicum virgatum, Scirpus fluviatilis, S. validus, Iris versicolor, Polygonum Muhlenbergii, Ranunculus delphinifolius, Vernonia fasciculata, Asclepias verticillata.

Upland species: Heuchera americana, Potentilla arguta, Petalostemum candidum, Baptisia leucantha, Desmodium illinoense, Gentiana puberula, 
Asclepias verticillata, Monarda fistulosa, Aster azureus, Liatris squarrosa, Solidago canadensis, Heliopsis scabra, Helianthus tuberosus, Monarda fistulosa, Artemisia ludoviciana.

The terminal or absorbing roots of four plants were studied and others were examined. The structure of the four roots drawn is typical and may be summarized as having a deep cortex (in this case 4/5-5/6 the radial depth of the stem) of aerenchyma or loose parenchyma, only a trace of, or no, mechanical tissue, and a variable vascular tissue with reference to the size and number of tracheae. It is evident that the function of these roots is absorption only. There is usually a little mechanical tissue in the upland species and a little more specialization of the vascular tissue.

Ranunculus multifidus has entirely a fibrous root and retains the primitive root character to maturity. It has no mechanical tissue.

Of the root structures studied, six were of upland plants and one of an alluvial basin plant. (Most of the prominent alluvial basin plants have rootstocks). Here parenchyma, found only in the cortex, was compact, reduction in space being supplemented by the presence of cork, collenchyma, or mechanical tissue. Reduction or absence of mechanical tissue was

\section{Comparison of Tissues of the Subterranean Organs}

Roots

\begin{tabular}{|c|c|c|c|c|c|c|}
\hline Name & Habitat & Root & $\begin{array}{l}\text { Radial } \\
\text { Depth } \\
\text { Cortex }\end{array}$ & Parenchyma & $\begin{array}{l}\text { Mechanical } \\
\text { Tissue }\end{array}$ & Vascular Tissue \\
\hline $\begin{array}{l}\text { Typha } \\
\text { latifolia }\end{array}$ & Al. bas. & Terminal & $4 / 5$ & Aerenchyma & None & $\begin{array}{c}\text { Fairly } \\
\text { prominent }\end{array}$ \\
\hline $\begin{array}{l}\text { Phragmites } \\
\text { communis }\end{array}$ & Al. bas. & Terminal & $5 / 7$ & Aerenchyma & Trace & $\begin{array}{l}\text { Distinct; not } \\
\text { prominent }\end{array}$ \\
\hline $\begin{array}{l}\text { Iris } \\
\text { versicolor }\end{array}$ & Al. bas. & Terminal & $5 / 6$ & Aerenchyma & Moderate & $\begin{array}{c}\text { Fairly } \\
\text { prominent }\end{array}$ \\
\hline $\begin{array}{l}\text { Vernonia } \\
\quad \text { fasciculata }\end{array}$ & Al. bas. & Primary & $\mathrm{I} / 2$ & $\begin{array}{l}\text { Aerenchyma } \\
\text { prominent; } \\
\text { parenchyma }\end{array}$ & Moderate & Limited; \\
\hline $\begin{array}{l}\text { Ranunculus } \\
\text { delphinifolius }\end{array}$ & Al. bas. & $\begin{array}{l}\text { Main } \\
\text { fibrous }\end{array}$ & $4 / 5$ & Aerenchyma & None & Limited \\
\hline $\begin{array}{l}\text { Polygonum } \\
\text { muhlenbergii }\end{array}$ & Al. bas. & Primary & $\mathrm{I} / 4$ & $\begin{array}{l}\text { Spongy } \\
\text { cork }\end{array}$ & Moderate & $\begin{array}{l}\text { Tracheae } \\
\text { numerous }\end{array}$ \\
\hline $\begin{array}{l}\text { Lepachys } \\
\text { pinnata }\end{array}$ & Upland & Terminal & $\mathrm{I} / 2$ & & Slight & $\begin{array}{l}\text { Tracheae } \\
\text { prominent }\end{array}$ \\
\hline $\begin{array}{l}\text { Potentilla } \\
\text { arguta }\end{array}$ & Upland & Primary & I $/ 6$ & Compact & Prominent & $\begin{array}{l}\text { Tracheae } \\
\text { large, } \\
\text { numerous }\end{array}$ \\
\hline $\begin{array}{c}\text { Desmodium } \\
\text { illinoense }\end{array}$ & Upland & Primary & $\mathrm{I} / 6$ & $\begin{array}{l}\text { Slight } \\
\text { cork }\end{array}$ & $\begin{array}{l}\text { Prominent } \\
\text { in stele }\end{array}$ & $\begin{array}{l}\text { Tracheae } \\
\text { large, few }\end{array}$ \\
\hline $\begin{array}{l}\text { Petalostemum } \\
\text { candidum }\end{array}$ & Upland & Primary & $\mathrm{I} / 6$ & $\begin{array}{c}\text { Thick-walled } \\
\text { cork }\end{array}$ & Prominent & $\begin{array}{l}\text { Tracheae } \\
\text { large, }\end{array}$ \\
\hline $\begin{array}{l}\text { Gentiana } \\
\text { puberula }\end{array}$ & Upland & Primary & $\mathrm{I} / 2$ & Prominent & Absent & $\begin{array}{l}\text { Tracheae } \\
\text { few }\end{array}$ \\
\hline $\begin{array}{l}\text { Solidago } \\
\text { canadensis }\end{array}$ & Upland & Secondary & $I / 2$ & $\begin{array}{l}\text { Parenchyma } \\
\text { thick-walled }\end{array}$ & Prominent & $\begin{array}{c}\text { Tracheae } \\
\text { large }\end{array}$ \\
\hline $\begin{array}{l}\text { Baptisia } \\
\text { leucantha }\end{array}$ & Al. bas. & Primary & $1 / 2$ & Prominent & Moderate & $\begin{array}{l}\text { Tracheae } \\
\text { few }\end{array}$ \\
\hline
\end{tabular}


Subterranean Stems

\begin{tabular}{|c|c|c|c|c|c|c|}
\hline Name & Habitat & $\begin{array}{l}\text { Subterranean } \\
\text { Stem }\end{array}$ & $\begin{array}{l}\text { Radial } \\
\text { Depth } \\
\text { Cortex }\end{array}$ & Parenchyma & $\begin{array}{l}\text { Mechanical } \\
\text { Tissue }\end{array}$ & Vascular Tissue \\
\hline $\begin{array}{l}\text { Typha } \\
\text { latifolia }\end{array}$ & Al. bas. & Rhizome & $\mathrm{I} / 2$ & Aerenchyma & $\begin{array}{l}\text { Slight in vas. } \\
\text { bund. sheath }\end{array}$ & $\begin{array}{c}\text { Fairly } \\
\text { prominent }\end{array}$ \\
\hline $\begin{array}{l}\text { Phragmites } \\
\text { communis }\end{array}$ & Al. bas. & Rhizome & $1 / 2$ & Aerenchyma & Clioht & Few bundles \\
\hline $\begin{array}{l}\text { Spartina } \\
\quad \text { Michauxiana }\end{array}$ & Al. bas. & Rhizome & $3 / 7$ & Slight & Prominent & $\begin{array}{l}\text { Vas. bundles } \\
\text { large, numerous }\end{array}$ \\
\hline $\begin{array}{l}\text { Panicum } \\
\text { virgatum }\end{array}$ & Al. bas. & Rhizome & $2 / 9$ & Slight & Prominent & $\begin{array}{l}\text { tracheae } \\
\text { Vas. bundles } \\
\text { large }\end{array}$ \\
\hline $\begin{array}{l}\text { Scirpus } \\
\text { fluviatilis }\end{array}$ & Al. bas. & Rhizome & $\mathrm{I} / 2$ & Aerenchyma & $\begin{array}{c}\text { In vas.bund. } \\
\text { sheaths }\end{array}$ & $\begin{array}{l}\text { Vas. bundles } \\
\text { numerous }\end{array}$ \\
\hline $\begin{array}{l}\text { Scirpus } \\
\text { validus }\end{array}$ & Al. bas. & Rhizome & $I / 3$ & Aerenchyma & $\begin{array}{l}\text { In vas.bund. } \\
\text { sheaths }\end{array}$ & Prominent \\
\hline $\begin{array}{l}\text { Iris } \\
\quad \text { versicolor }\end{array}$ & Al. bas. & Rhizome & $\mathrm{I} / 3$ & Aerenchyma & $\begin{array}{c}\text { In vas.bund. } \\
\text { sheaths }\end{array}$ & Prominent \\
\hline $\begin{array}{l}\text { Polygonum } \\
\text { Muhlenbergii }\end{array}$ & Al. bas. & Rhizome & $\mathrm{I} / 6$ & Aerenchyma & $\begin{array}{l}\text { Absent ex- } \\
\text { cept few } \\
\text { wood cells }\end{array}$ & Slight \\
\hline $\begin{array}{l}\text { Asclepias } \\
\text { verticillata }\end{array}$ & Al. bas. & Rhizome & $\mathrm{I} / 4$ & Prominent & Ahse & Tracheae few \\
\hline $\begin{array}{l}\text { Monarda } \\
\text { fistulosa }\end{array}$ & Al. bas. & Rhizome & $\mathrm{I} / 4$ & Prominent & Slight & Tracheae few \\
\hline $\begin{array}{l}\text { Heuchera } \\
\text { Americana }\end{array}$ & Upland & Rhizome & $\mathrm{I} / 5$ & Prominent & Absent & $\begin{array}{l}\text { Tracheae; } \\
\text { tissue small }\end{array}$ \\
\hline $\begin{array}{l}\text { Viola } \\
\quad \text { pedata }\end{array}$ & Upland & Rhizome & $\mathrm{I} / 4$ & Prominent & Absent & $\begin{array}{c}\text { Tracheae small, } \\
\text { numerous }\end{array}$ \\
\hline $\begin{array}{l}\text { Aster } \\
\text { azureus }\end{array}$ & Upland & Rhizome & $\mathrm{I} / 7$ & $\begin{array}{l}\text { Cork slight; } \\
\text { parenchyma }\end{array}$ & $\begin{array}{c}\text { Fairly } \\
\text { prominent }\end{array}$ & $\begin{array}{l}\text { Tracheae } \\
\text { numerous }\end{array}$ \\
\hline $\begin{array}{l}\text { Antennaria } \\
\quad \text { plantaginifolia }\end{array}$ & Upland & Rhizome & $\mathrm{I} / 4$ & po & $\begin{array}{c}\text { Prominent } \\
\text { wood fibers }\end{array}$ & $\begin{array}{l}\text { Tracheae small, } \\
\text { inconspicuous }\end{array}$ \\
\hline $\begin{array}{l}\text { Liatris } \\
\text { squarrosa }\end{array}$ & Upland & Corm & $\mathrm{I} / 6$ & Compact & Prominent & $\begin{array}{c}\text { Few tracheae; } \\
\text { small }\end{array}$ \\
\hline $\begin{array}{l}\text { Heliopsis } \\
\text { scabra }\end{array}$ & Upland & Rhizome & $\mathrm{I} / 9$ & Slight & Prominent & $\begin{array}{c}\text { Tracheae } \\
\text { numerous }\end{array}$ \\
\hline $\begin{array}{l}\text { Lepachys } \\
\text { pinnata }\end{array}$ & Upland & Rhizome & $\mathrm{I} / 6$ & Slight & Prominent & $\begin{array}{l}\text { Tracheae } \\
\text { small, few }\end{array}$ \\
\hline $\begin{array}{l}\text { Artemisia } \\
\text { ludoviciana }\end{array}$ & Upland & Rhizome & $\mathrm{I} / 4$ & Prominent & Moderate & Few tracheae \\
\hline $\begin{array}{l}\text { Helianthus } \\
\text { tuberosus }\end{array}$ & Upland & Rhizome & $\mathrm{I} / 4$ & Prominent & Slight & Tracheae few \\
\hline
\end{tabular}

prominent in 66 percent of the roots. Tracheae were generally large and quite numerous.

The only thick root of the alluvial basin studied was that of Baptisia leucantha, which had prominent parenchyma, moderate mechanical tissue, and few tracheae.

The subterranean stems of ten alluvial basin and nine upland plants were examined. Of the alluvial basin plants, 65 percent had aerenchyma and only Io percent reduced parenchyma. In only io percent was mechanical tissue prominent though present about the sheaths of monocotyledons. In the monocotyledons the vascular tissue was fairly prominent; in dicotyledons it was poorly developed.

In the stems of the upland plants there is considerable variation in the 
relative proportion of parenchyma, though in the plants of the drier habitats it was present in very slight degree. Mechanical tissue was prominent in most of the plants with large aerial portions, and usually absent in the low-growing plants with the exception of Helianthus which seems to be a non-conformist in both leaf and stem characters and lives by a code of its own. The tracheae were also variable in size and number. In this small group of plants no correlation could be seen between the number of tracheae and the number of leaves. The presence of thick-walled cells not only serves as a reinforcing character but no doubt tends to preserve turgor and to protect water-conducting tissues against loss of water.

\section{SUMMARY}

A study of the minute anatomy of subterranean organs of prairie plants shows:

(I) There is a tendency to the production of prominent mechanical tissue in plants of dry habitats and reduction of parenchymatous tissue.

(2) In moist habitats the proportion of parenchymatous tissue is prominent. Aerenchyma is abundant in swamp plants.

(3) The vascular tissue is variable in quantity, seemingly more or less subject to systematic variation.

The subterranean stem is predominant as an equivalent of the primary root, especially in moist lowland regions. It is more efficient than the root in propagation. Primary roots which show secondary thickening resemble stems in their concentric manner of expansion. The stem has an area of pith which serves as a reservoir for water and hence increases its efficiency for radial distribution.

I wish to acknowledge the helpful comment of Dr. L. H. Pammel, Dr. J. N. Martin, and Miss Charlotte M. King in the preparation of this paper.

Iowa State College, Ames, Iowa

\section{LITERATURE CITED}

I. Britton, N. L., and Brown, A. An illustrated flora of the northern United States, Canada and the British possessions. 3 vol. New York, I896.

2. Cannon, W. A. Water conducting system of some desert plants. Bot. Gaz. 39: 396. I905.

3. - The root habits of desert plants. Carn. Ins. Wash. Publ. I3I. I9I I.

4. Chauveaud, G. L'appareil conducteur des plantes vasculaires et les phases principales de son évolution. Ann. Sci. Nat. IX. Bot. I3: II3-438. I9I I.

5. - Recherches sur les tissues transitoires du corps végétatif des plantes vasculaires. Ann. Sci. Nat. I X. Bot. I2: I-70. I9Io.

6. Dauphiné, A. Recherches sur les variations de la structure des rhizomes. Ann. Sci. Nat. I X. Bot. 3: 317-368. 1906.

7. De Bary, A. Comparative anatomy of the vegetative organs of the phanerogams and ferns. Transl. by Bower and Scott. Oxford, I884.

8. Gray, A. New manual of botany. 7th ed. Revised by Robinson and Fernald. New York, 1908. 
9. Haberlandt, G. Physiological plaut anatomy. Transl. by Montagu Drummond. London, I9I4.

Io. Häckel, E. Über einige Eigenthümlichkeiten der Gräser trockener Klimate. Verh.' Zool. Bot. Ver. Wien. I890. I25-I38.

II. Harshberger, J. W. The vegetation of the New Jersey pine-barrens. Philadelphia, I9I6.

I2. Hess, E. Über die Wuchsformen der Alpinen Geröllpflanzen. Dișs. Universität Zürich. I909.

I3. Holm, T. The grasses of dry climates. Bot. Gaz. I6: 87-89. I89I.

I4. Jeffrey, E. C. The anatomy of woody plants. Chicago, I9I7.

I5. Jodin, H. Recherches anatomiques sur les Borraginées. Ann. Sci. Nat. VIII. Bot. I7: 263-346. plates V-I X. I903.

I6. Maxwell, F. B. A comparative study of the roots of Ranunculaceae. Bot. Gaz. Io: $8,41,97$.

I7. Scherff, E. E. The vegetation of Skokie Marsh, with special reference to subterranean organs and their interrelationships. Bot. Gaz. 53:4I5-435. I9I2.

I8. Yapp, R. H. On stratification in the vegetation of a marsh, and its relations to evaporation and temperature. Annals of Botany 23: 275-319. plate XX. 1909.

\section{EXPLANATION OF PLATES XV-XXVIII}

$A$, aerenchyma; $B$, bast; $C$, collenchyma; $C M$, cambium; $C K$, cork; $E N$, endodermis; $E P$, epidermis; $P$, parenchyma; $P H$, phloem; $R C$, resin canal; $S C$, sclerenchyma; $R H$, root hair; $T$, tracheae; $X$, xylem; $P X$, protoxylem; $M X$, metaxylem; $W F$, wood fibers; $W P$, wood parenchyma; $W R$, wood rays; $V B$, vascular bundle.

The figures were made with the aid of a camera lucida. The compound microscope was a Spencer, Oculars $5 \times$ and $10 X$ and objectives 4 and 16 , with a standard tube length, were used in various combinations.

\section{Plate XV}

Subterranean Systems of Water Plants

FIG. a. Polygonum Muhlenbergii.

FIG. b. Phragmites communis.

FIG. c. Scirpus fluviatilis.

FIG. d. Typha latifolia.

FIG. e. Iris versicolor.

FIG. $f$. Sagittaria latifolia.

FIG. g. Scirpus validus.

FIG. h. Spartina Michauxiana.

Plate XVI

FIG. I. Typha latifolia, rhizome, $\times 75$.

Fig. 2. Typha latifolia, root, $\times 93$.

Plate XVII

FIG. I. Phragmites communis, rhizome, $X$ I 50 .

FIG. 2. Phragmites communis, root, $X$ II 5 .

Plate XVIII

FIG. I. Spartina Michauxiana, rhizome, $X 125$.

FIG. 2. Panicum virgatum, rhizome, $X$ I02.

\section{Plate XIX}

FIG. I. Iris versicolor, rhizome, $\times 50$.

FIG. 2. Iris versicolor, root, $\times 75$.

FIG. 3. Scirpus fluviatilis, rhizome, $\times 50$. 


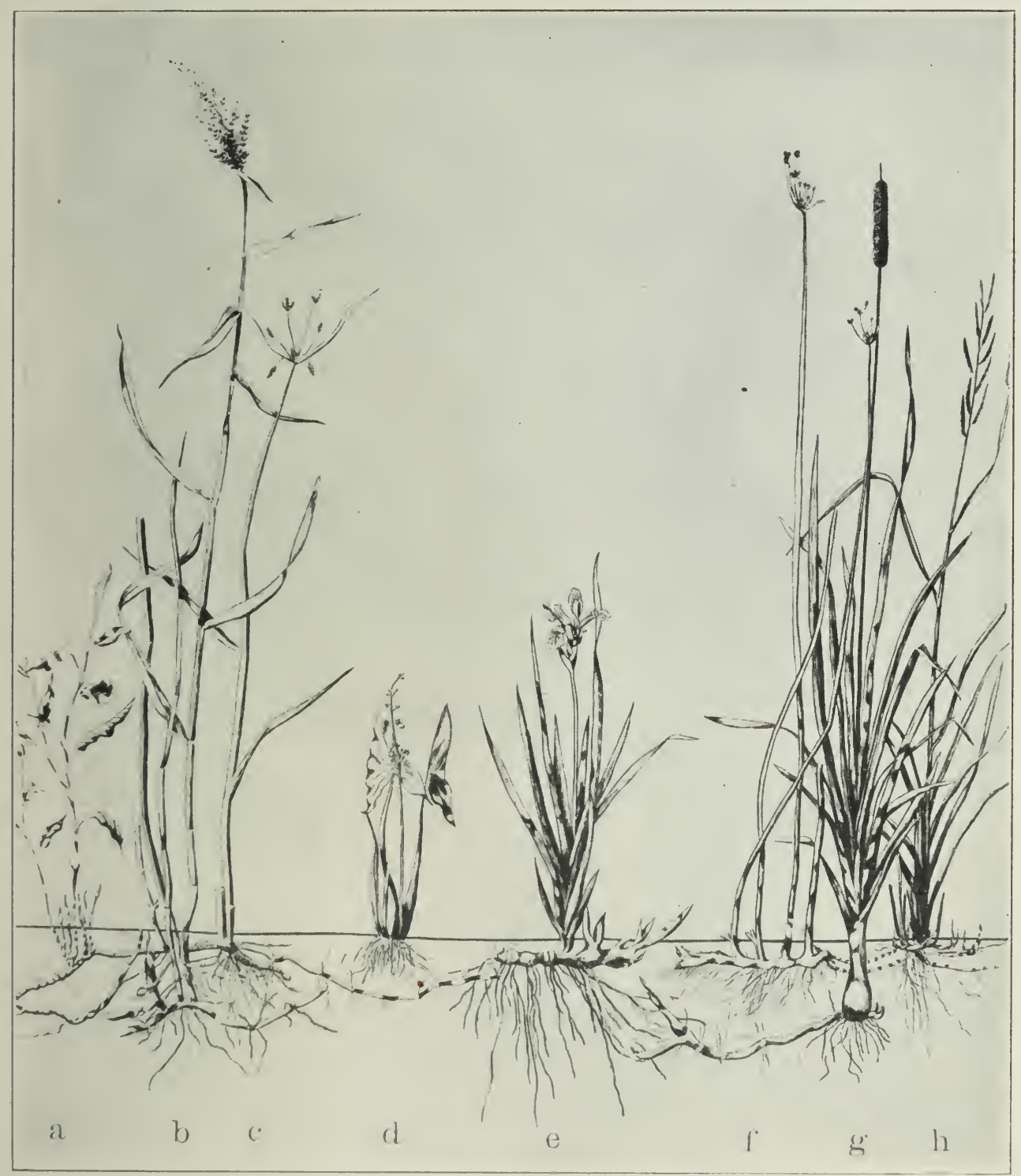




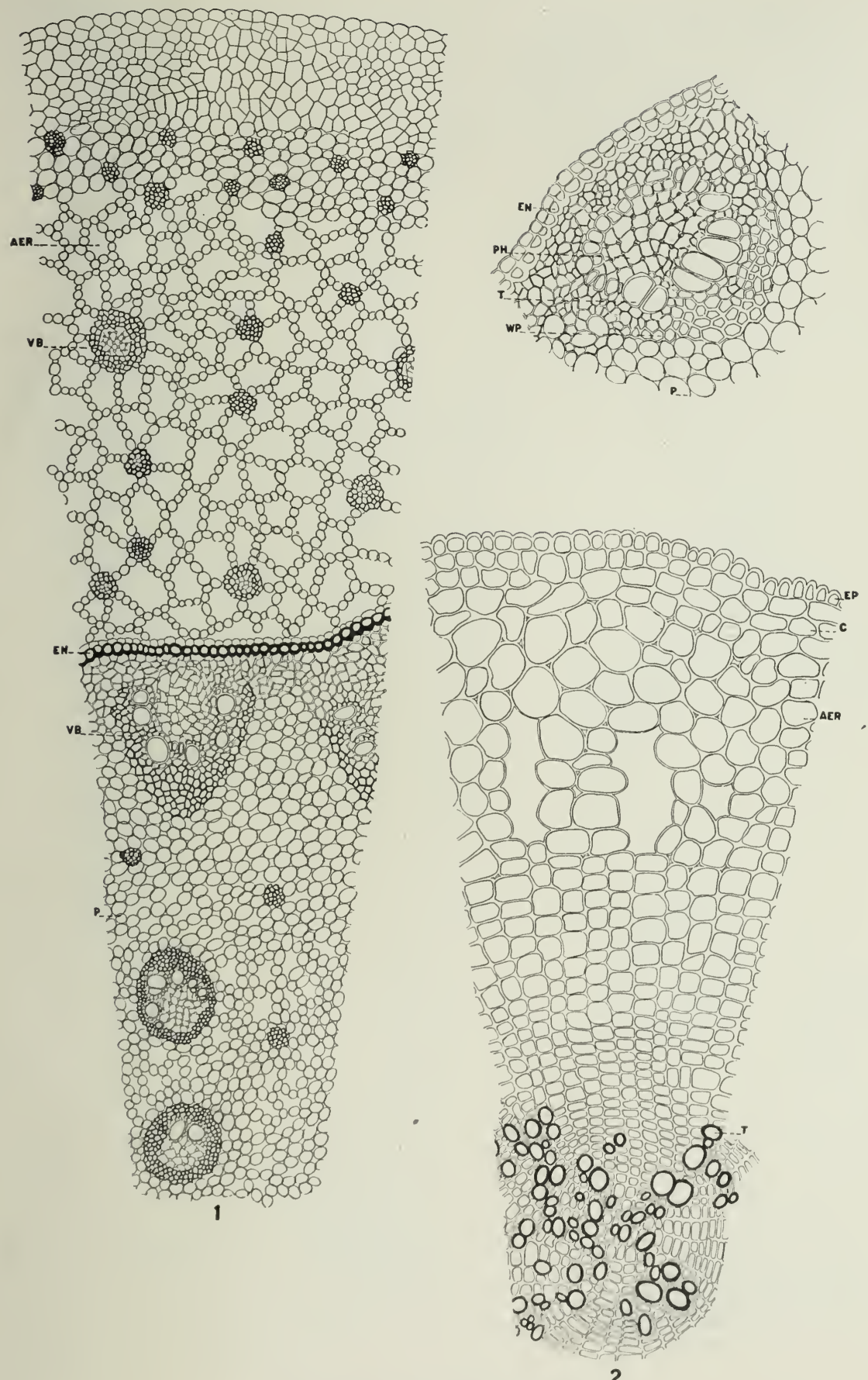

Hayden: Ecologic Anatomy. 


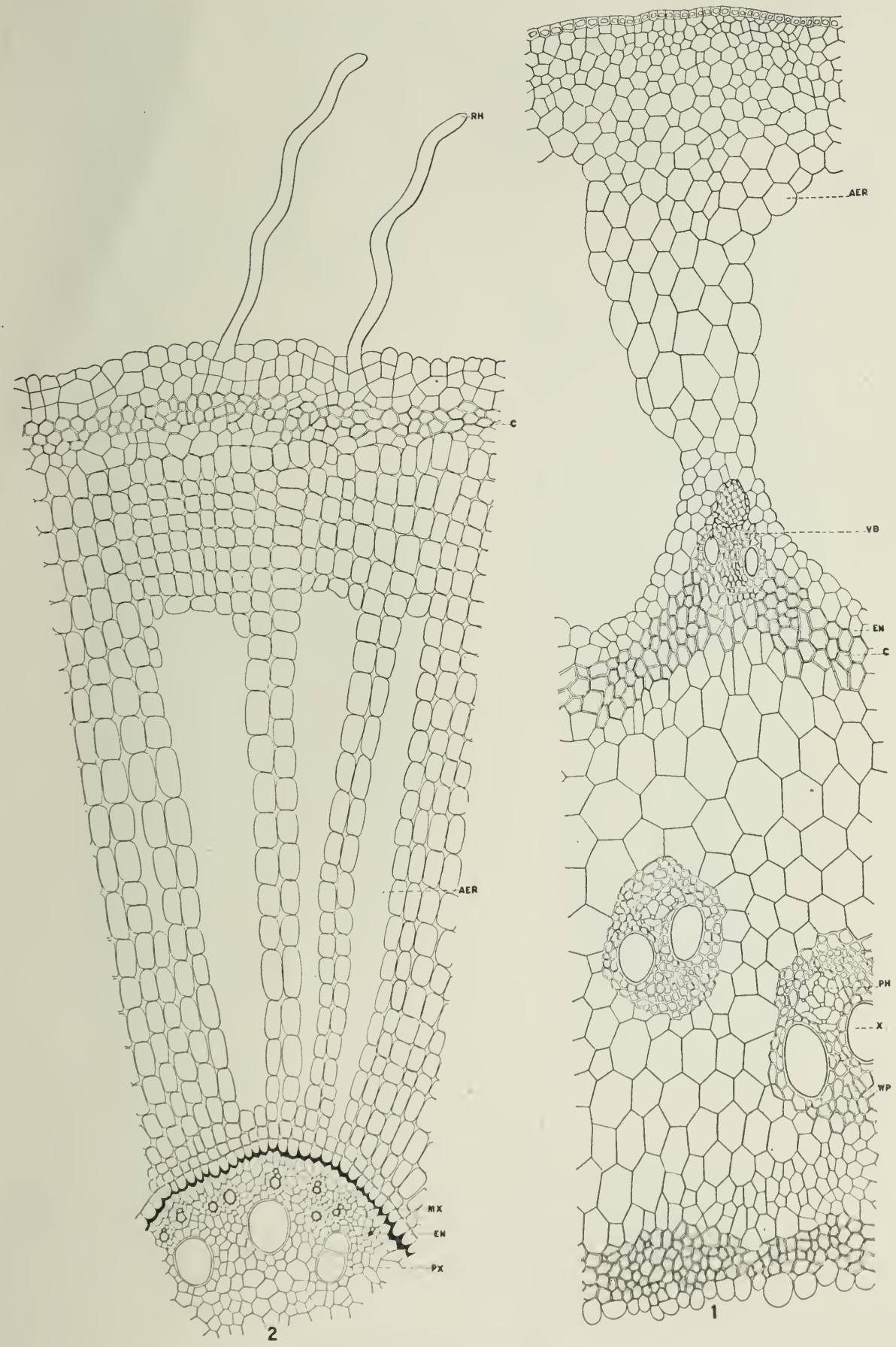

Hayden: Ecologic Anatomy. 


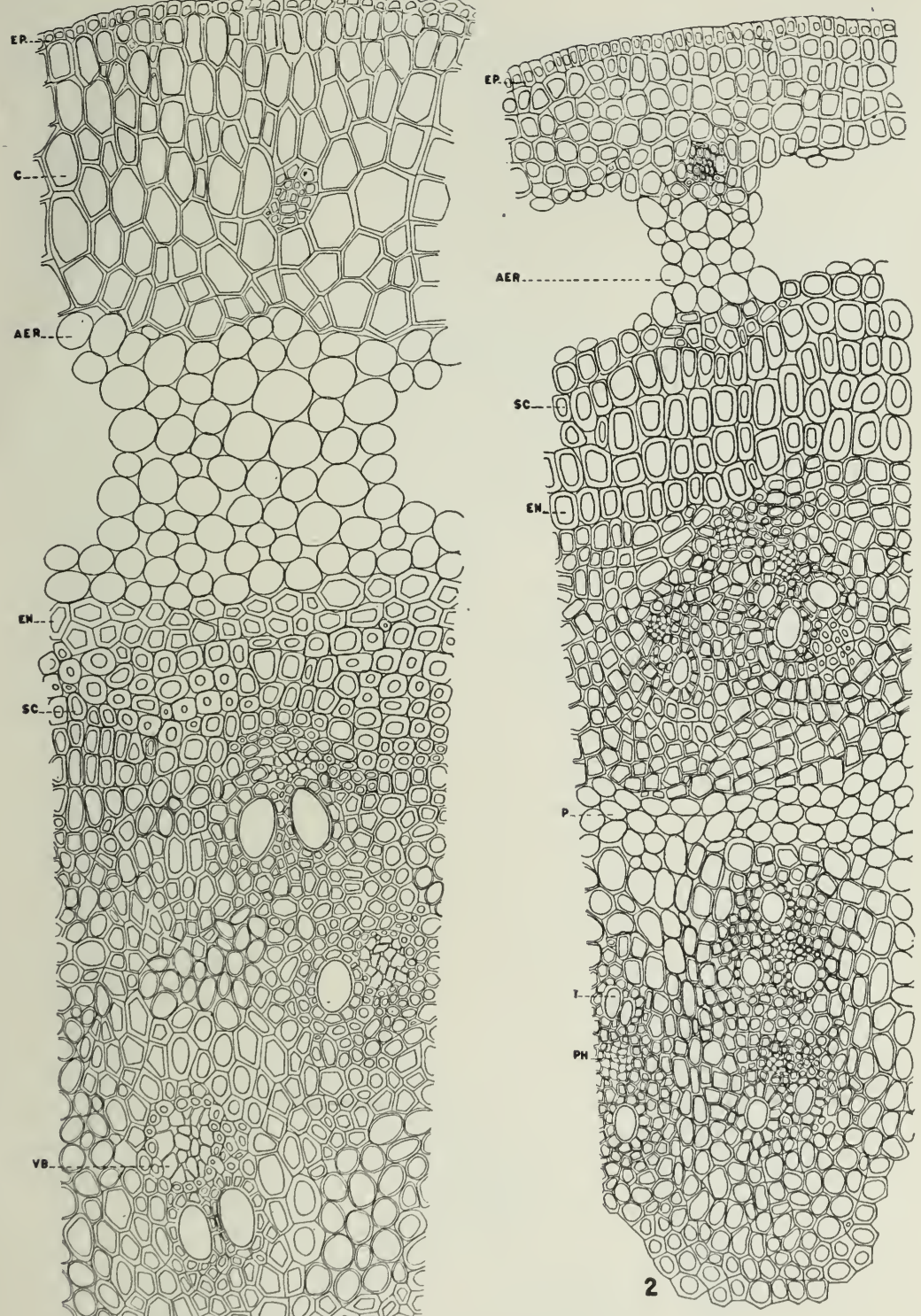

-. 0101010

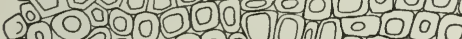
\% 0 O O O 010 (0)

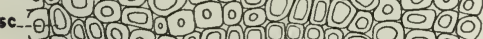
000010 0 0 0 \% $30000.02010035050 \%$

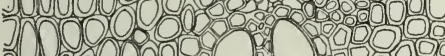
2001000 8000

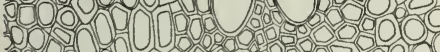

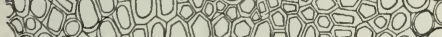

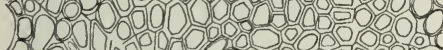
3. 1000001000 , $200001000000 \%$

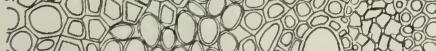

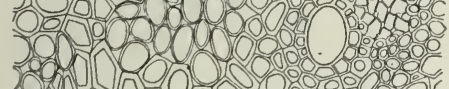
520 - 00000089

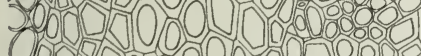

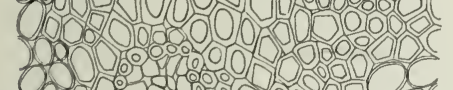

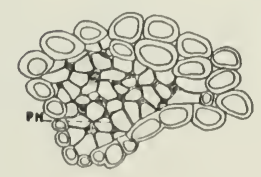





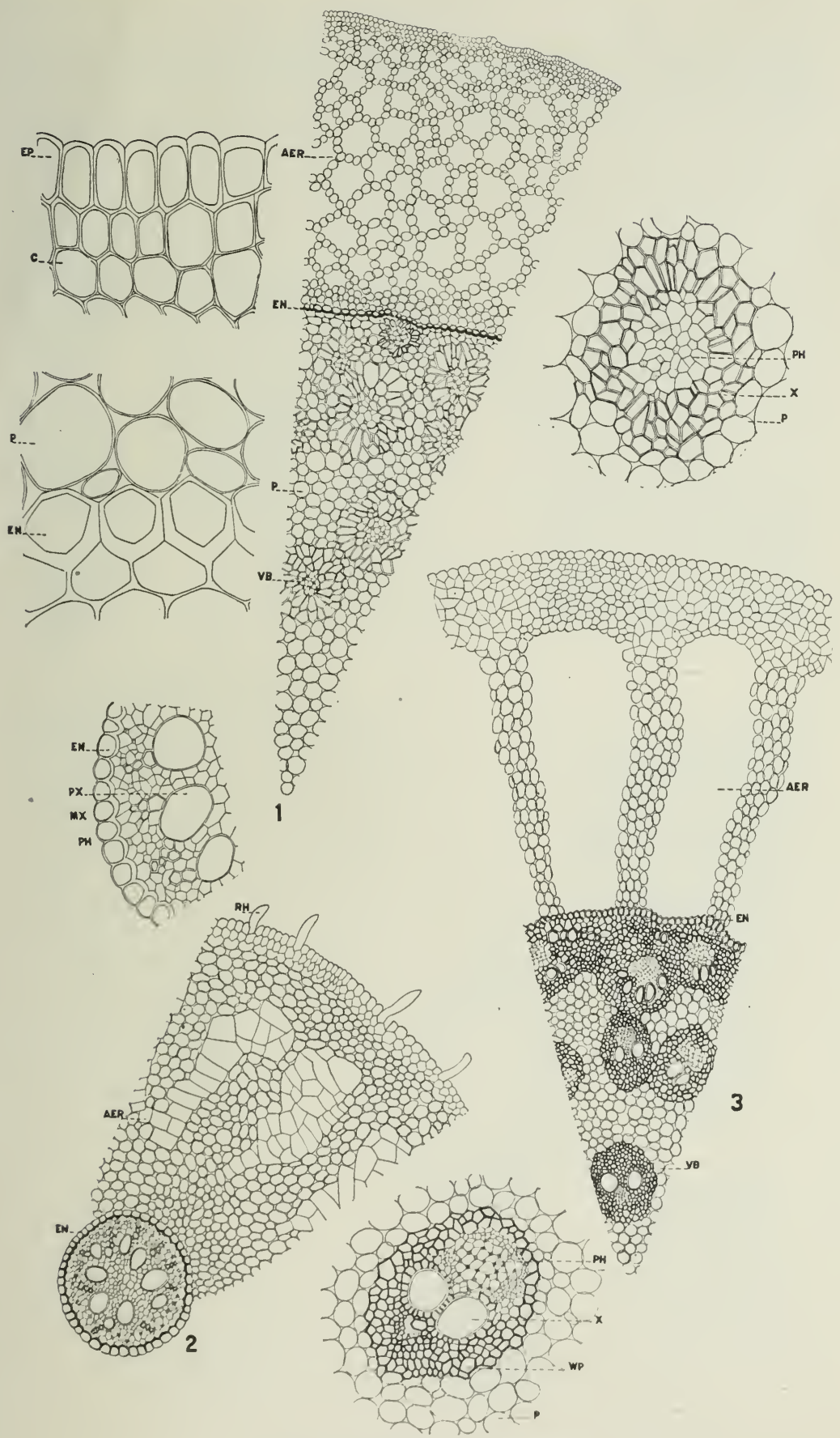

Hayden: Ecologic Anatomy. 


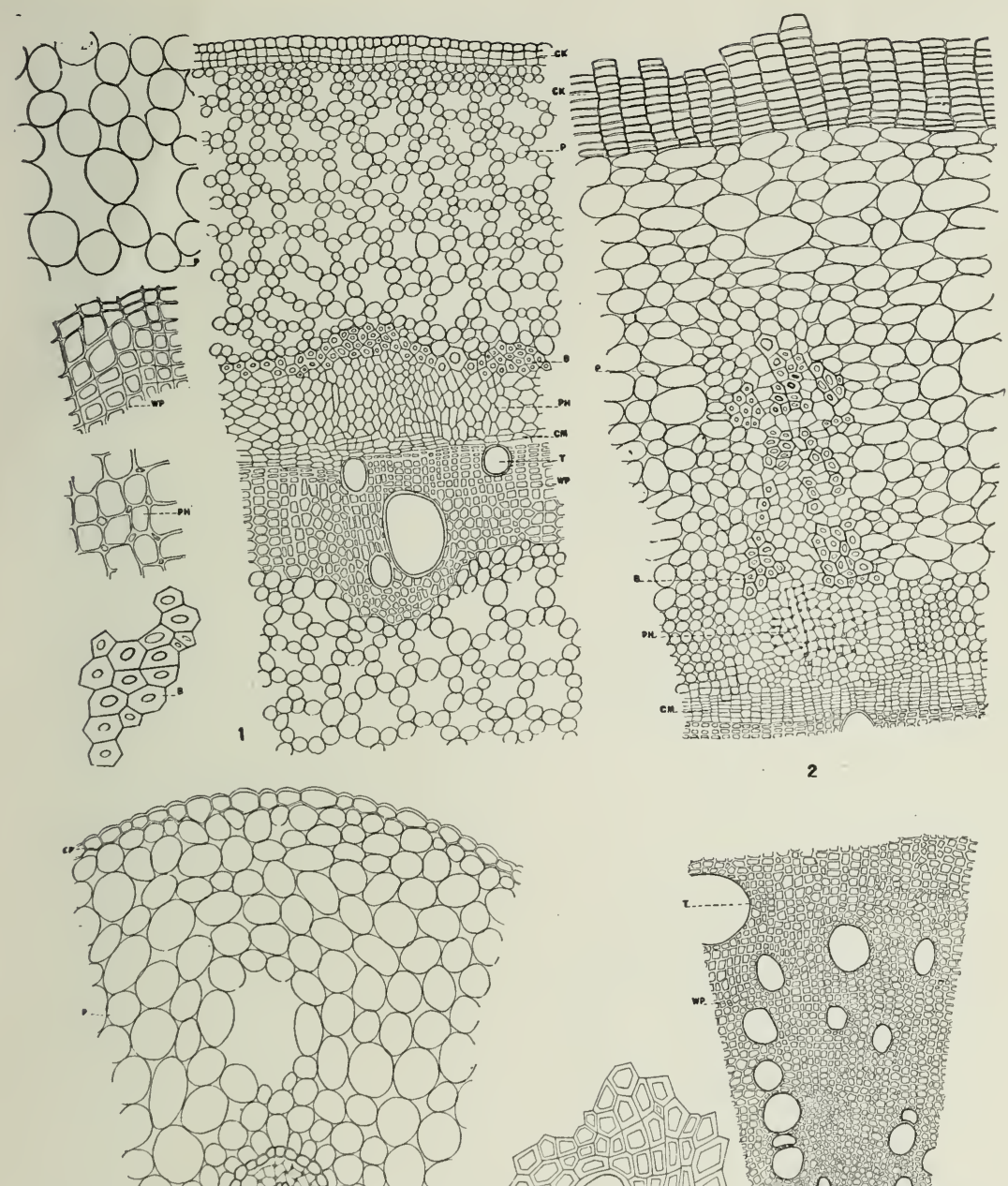

.
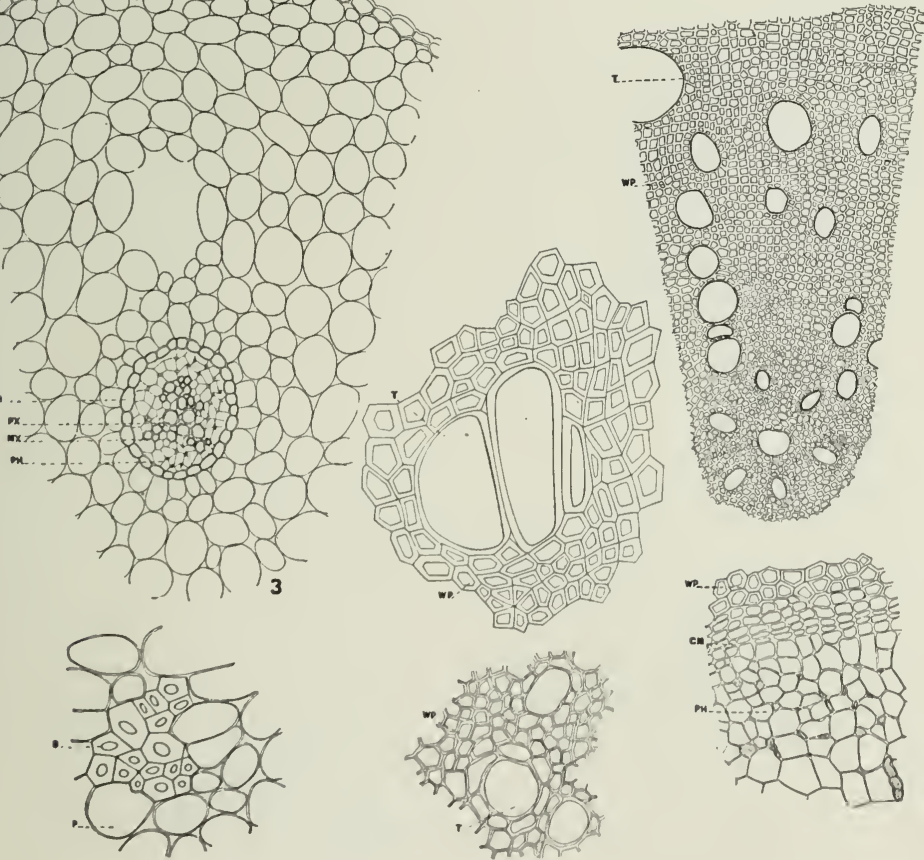

Hayden: Ecologic Anatomy. 


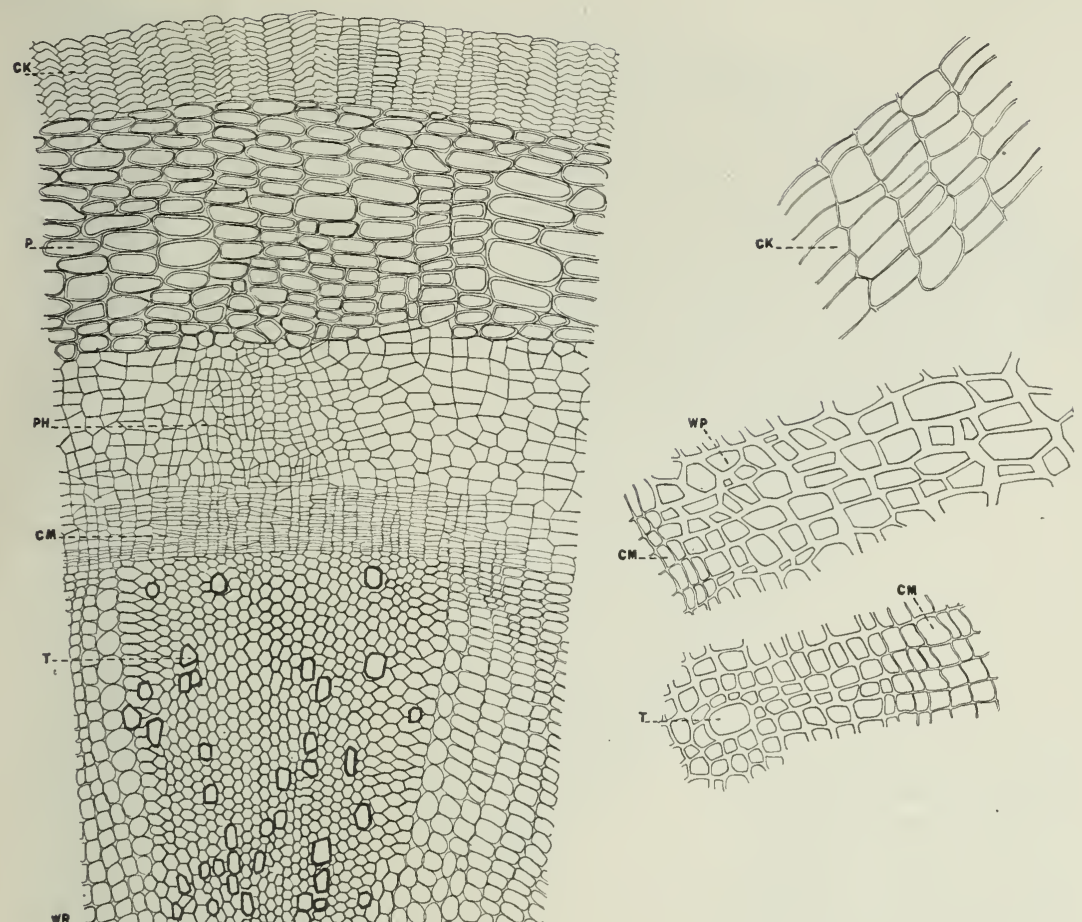

$\mathrm{cm}_{-}-\mathrm{f}$

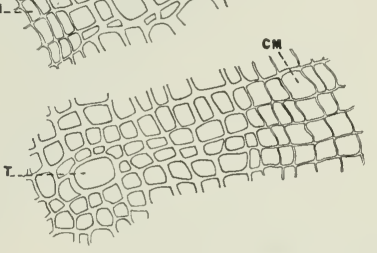

*- 7 - $=001000$

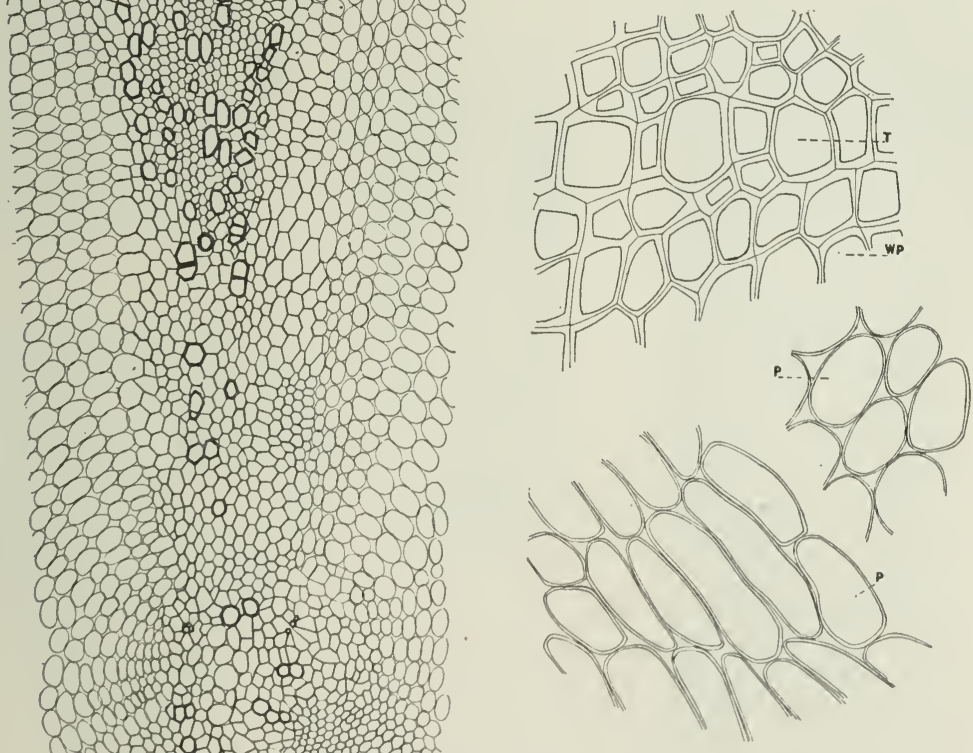

800 J

Hayden: Ecologic Anatomy. 


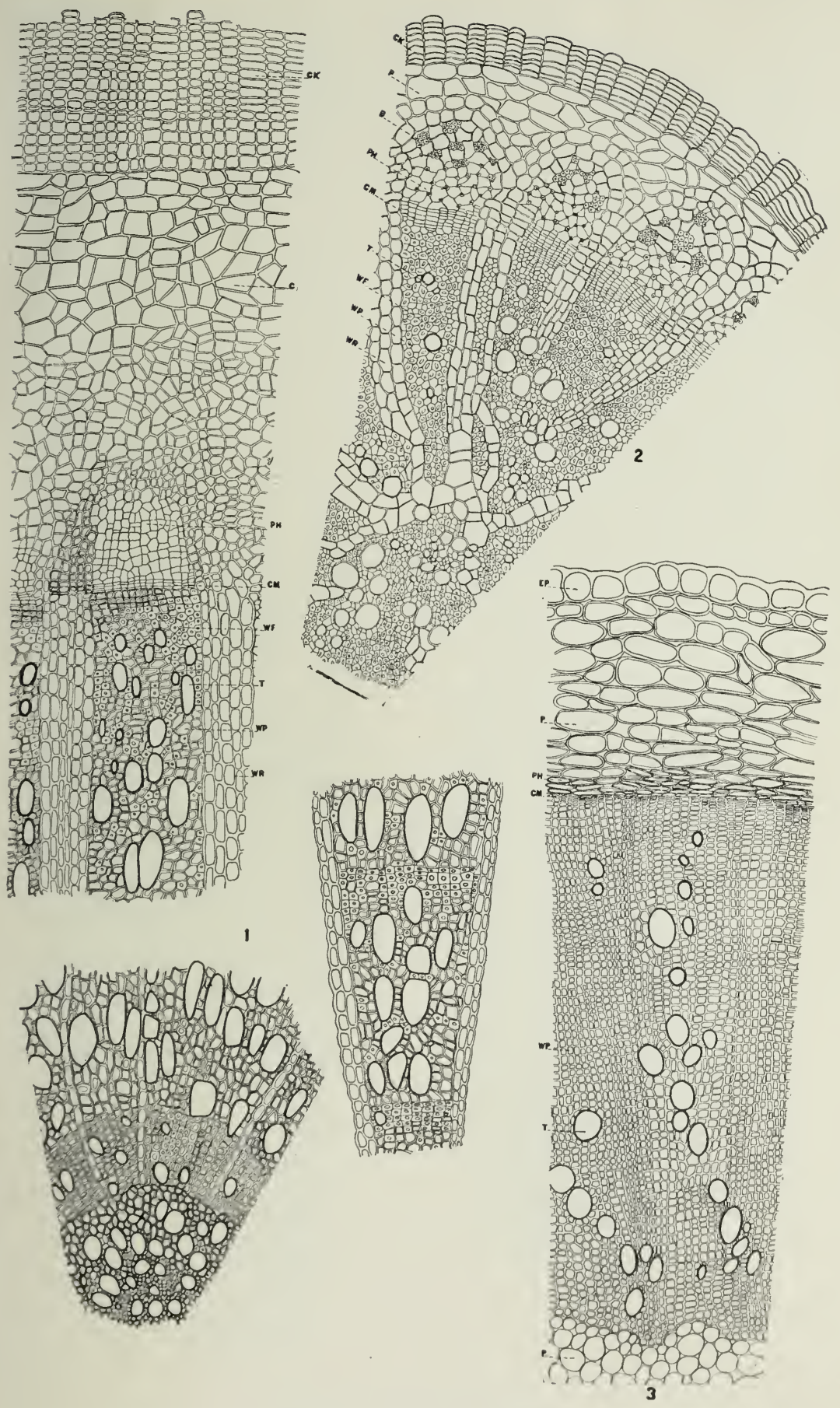

Hayden: Ecologic Anatomy. 



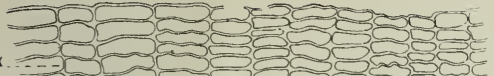

$-303030-302030$

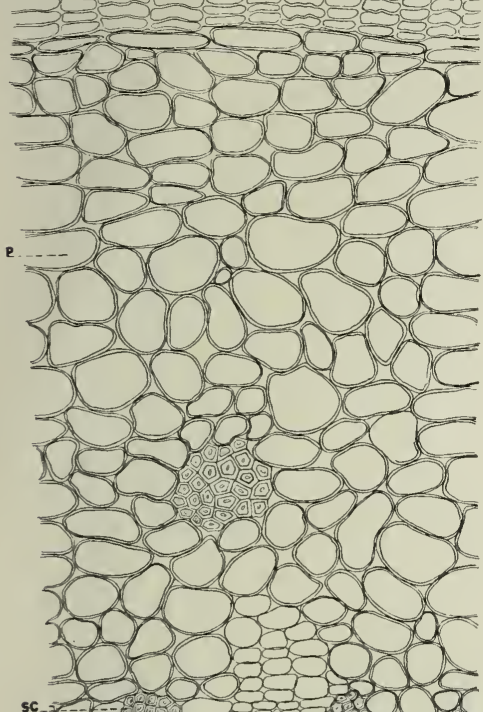

sc.
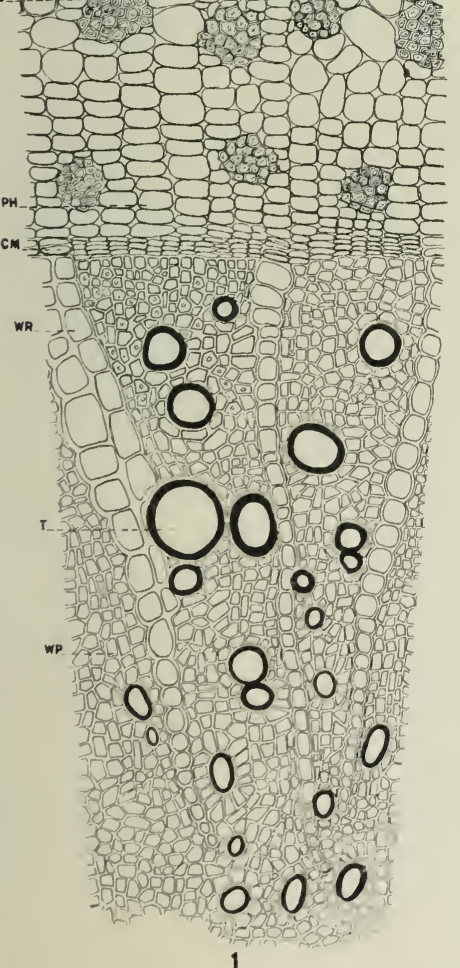

00

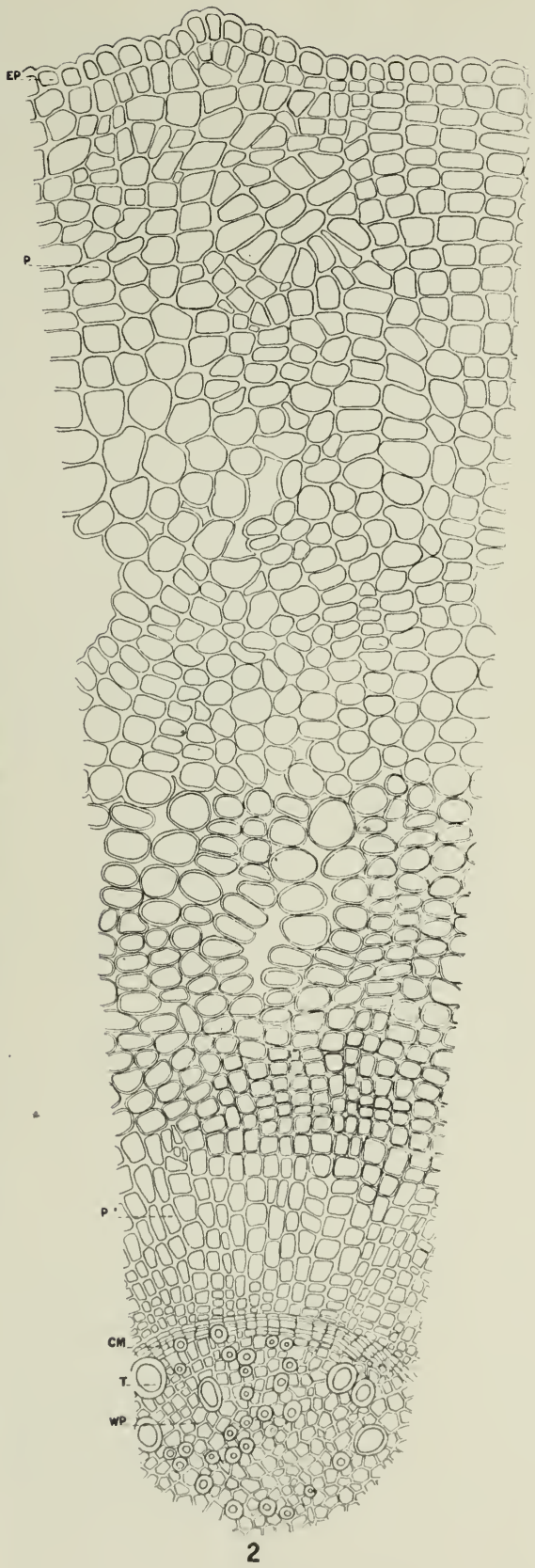

HAYDEN: ECOLOGic ANatomy. 


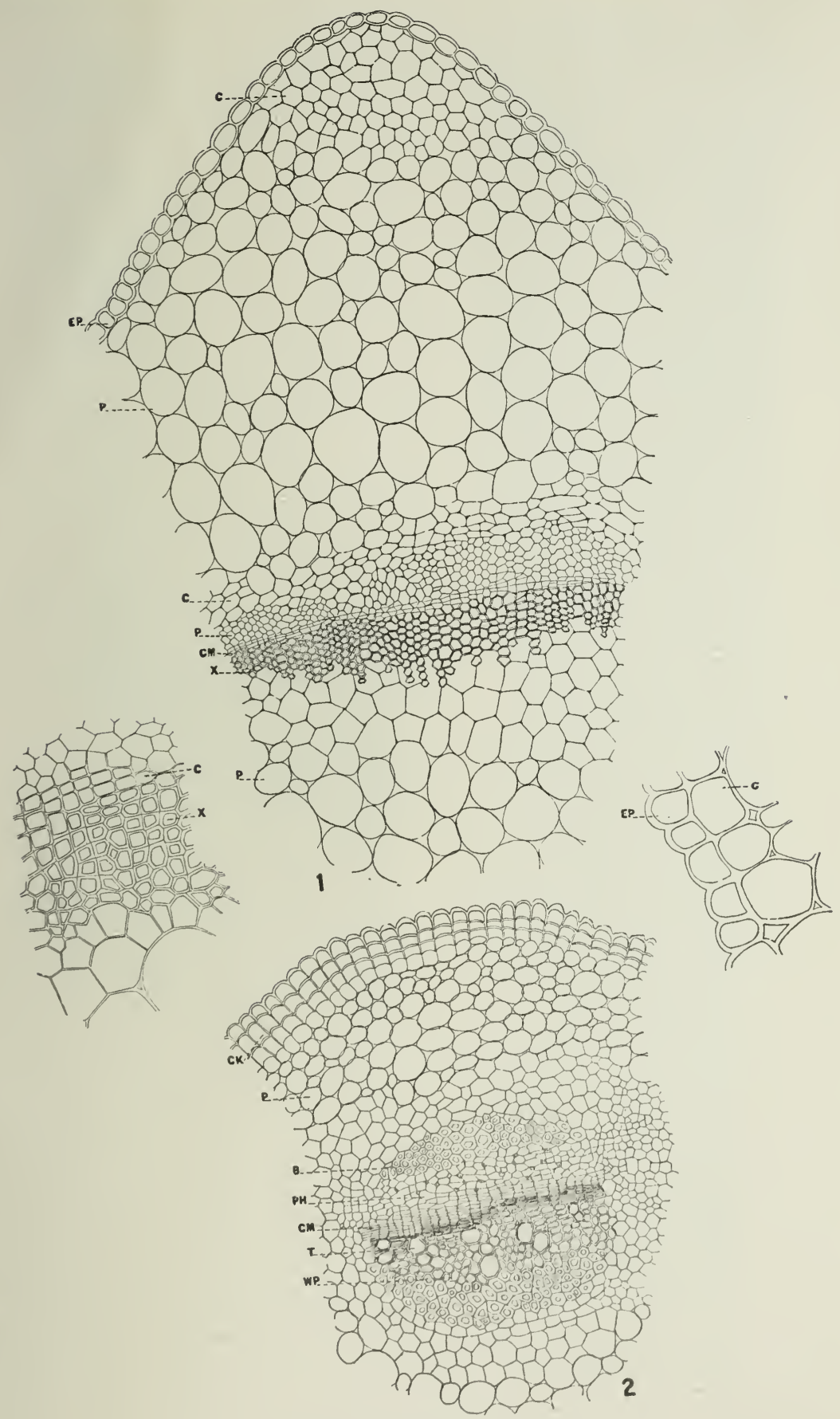

Hayden: Ecologic Anatomy. 


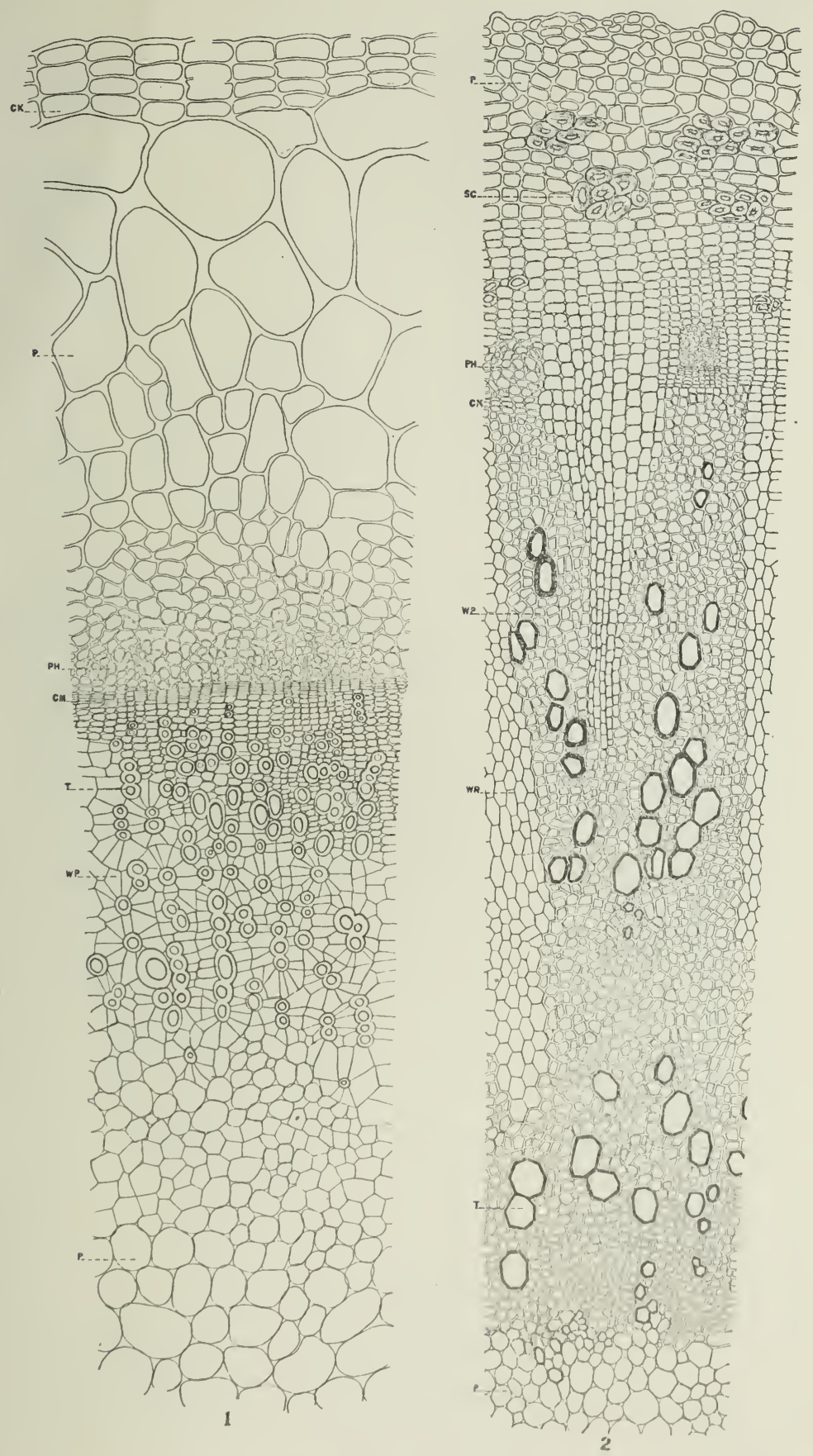

Hayden: Ecologic Anatomy. 


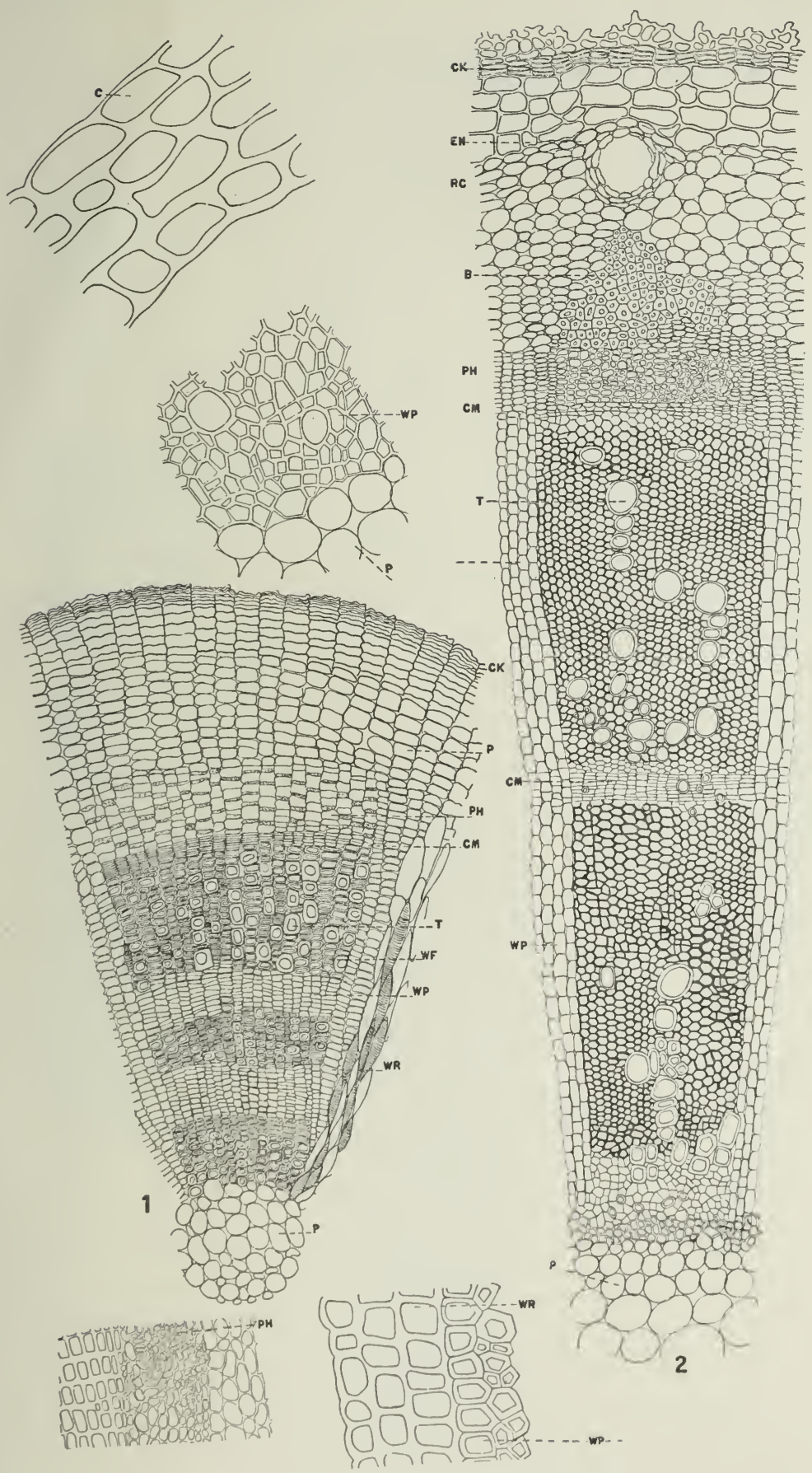

HAyden: ECOlogic AnAtomy. 



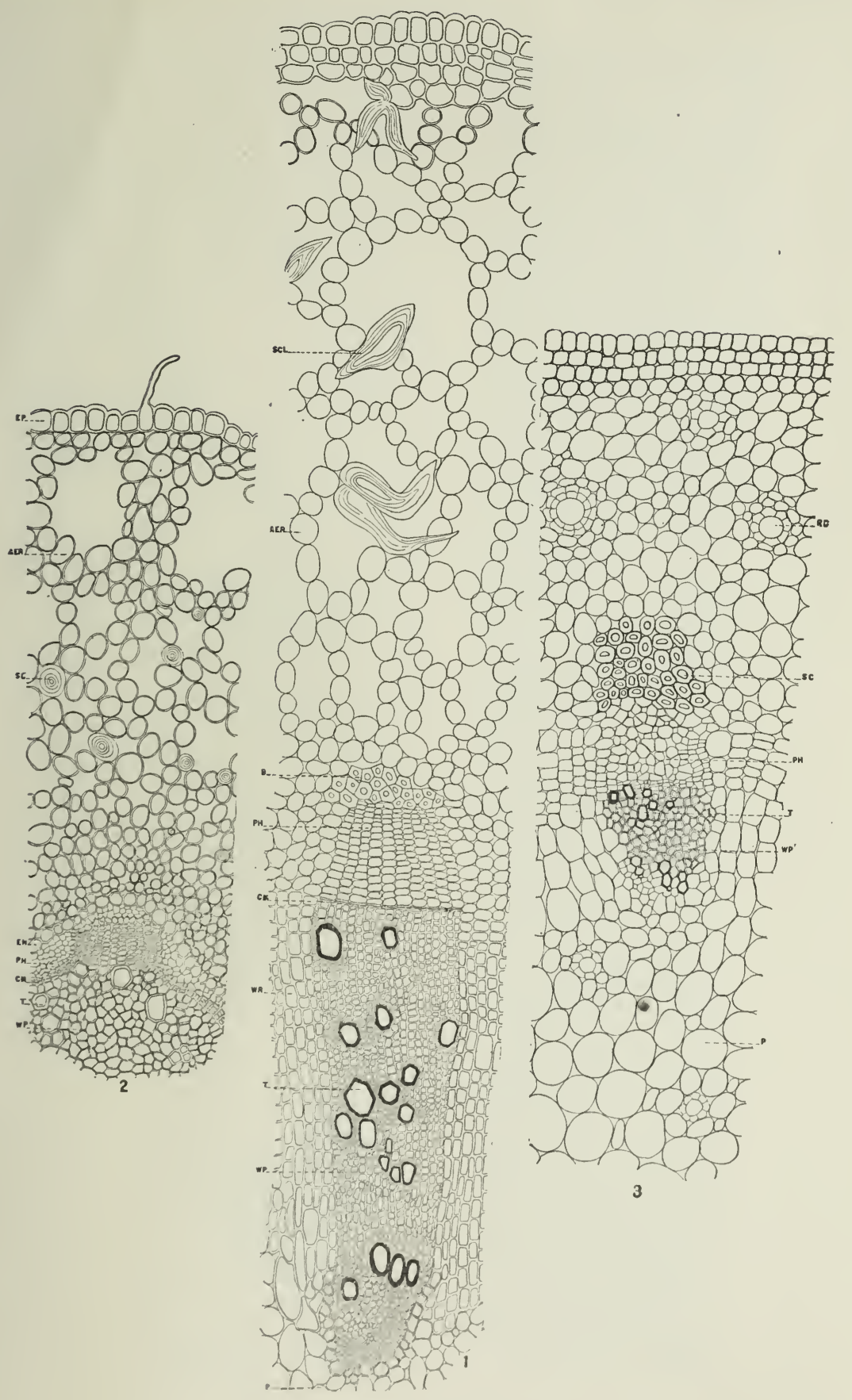

Ha yden: Ecologic Anatomy. 


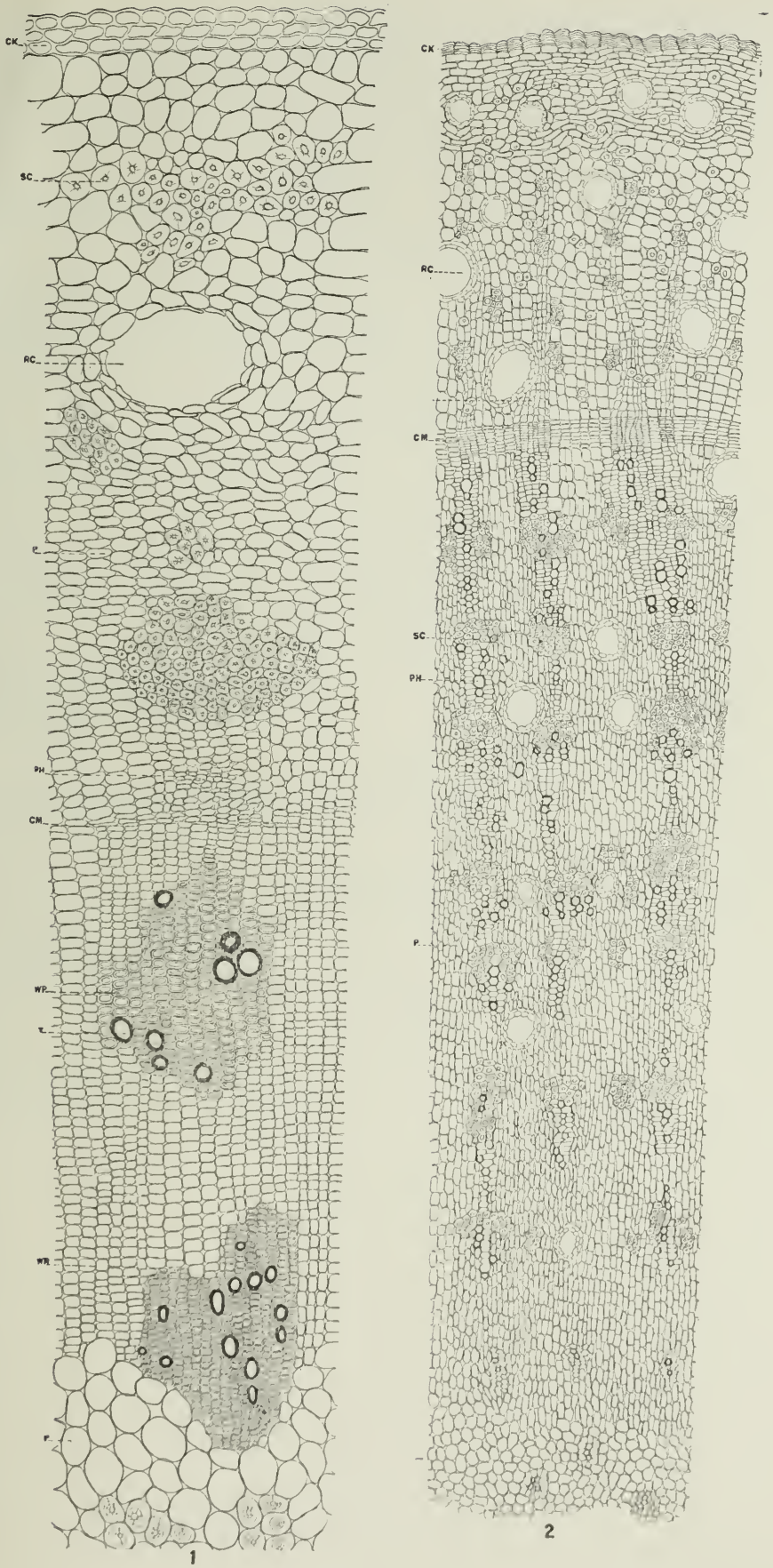

Hayden: Ecologic Anatomy. 



\section{Plate XX}

FIG. I. Polygonum Muhlenbergii, rhizome, $\times 45$.

FIG. 2. Polygonum Muhlenbergii, root, $\times 45$.

FIG. 3. Ranunculus delphinifolius, root, $\times$ Ioo.

\section{Plate XXI}

FIG. I. Heuchera americana, rhizome, $\times 80$.

\section{Plate XXII}

FIG. I. Potentilla arguta, root, $\times$ гоo.

FIG. 2. Petalostemum candidum, root, $\times 75$.

FIG. 3. Asclepias verticillata, rhizome, $\times 75$.

\section{Plate XXIII}

FIG. I. Baptisia leucantha, root, $X$ I50.

FIG. 2. Gentiana puberula; root, $\times$ I50.

\section{Plate XXIV}

FIG. I. Monarda fistulosa, rhizome, $X$ I25.

FIG. 2. Artemisia ludoviciana, rhizome, $\times 50$.

\section{Plate XXV}

FIG. I. Viola pedata, rhizome, $\times 75$.

FIG. 2. Heliopsis scabra, rhizome, $\times 90$.

\section{Plate XXVI}

FIG. I. Antennaria plantaginifolia, rhizome, $X 165$.

FIG. 2. Aster azureus, rhizome, $X$ i 10.

\section{Plate XXVII}

FIG. I. Vernonia fasciculata, rhizome, $\times 60$.

FIG. 2. Vernonia fasciculata, root, $\times 90$.

FIG. 3. Helianthus tuberosus, rhizome, $\times 76$.

\section{Plate XXVIII}

FIG. I. Lepachys pinnata, rhizome, $\times 85$.

FIG. 2. Liatris squarrosa, corm, $X \mathrm{I} 6$. 



\section{.}


